IRSH 53 (2008), pp. 63-99 DOI: 10.1017/So020859007003343

(C) 2008 Internationaal Instituut voor Sociale Geschiedenis

\title{
Class, Nation, and Capitalist Globalization: Eric Hobsbawm and the National Question
}

\author{
Wade MatTHEWS
}

Summary: This article will argue that scholars concerned with the nexus between socialism and nationalism have overlooked the work of Eric Hobsbawm, the foremost present-day Marxist historian and a key theorist of modern nationalism. The article will repair that neglect by providing the first systematic analysis of Hobsbawm's encounter with the national question. It will contend that Hobsbawm's work is a key site for those interested in exploring the clash between classconsciousness and national identity, and that his historical and political writing provides a unique window on the nexus between nationalism and socialism in the last half of the twentieth century. The article will also suggest that Hobsbawm's changing conception of the relationship between nationalism and socialism is crucial to an understanding of the shifts his politics have undergone in the last three decades or so.

Eric Hobsbawm is "the premier Marxist historian working today". ${ }^{\mathrm{I}}$ This assessment is not simply based on the extent of a disciplinary expertise which traverses centuries, continents and cultures, across social, political, and economic history. It is founded on Hobsbawm's mastery of generalization and synthesis and a corresponding ability to incorporate "theory" and "history" into his historical practice." The combination of these strengths of breadth, craft and detail was particularly evident in his analysis of the national question. Perhaps more than any other twentieth-century Marxist historian, Hobsbawm has persistently addressed issues of

I. This assessment was made as long ago as 1978. For the citation, see H. Kaye, The British Marxist Historians: An Introductory Analysis (New York, 1985), p. I3 I. For the earlier assessment, see J. Cronin, "Creating a Marxist Historiography: The Contribution of Hobsbawm", Radical History Review, I9 (1978-1979), p. 88. The political appellation could be dropped from this statement without causing argument. This was the opinion of Edward Said. See E. Said, "Contra Mundane: On Eric Hobsbawm", in idem, Reflections on Exile and Other Literary and Critical Essays (London, 2000), p. 474. For a general assessment of Hobsbawm's historical practice, see E.D. Genovese, "The Politics of Class Struggle in the History of Society: An Appraisal of the Work of Eric Hobsbawm", in P. Thane, G. Crossick, and R. Floud (eds), The Power of the Past: Essays for Eric Hobsbawm (London, 1984), pp. I3-36.

2. For a similar judgment, see R. Samuel and G. Stedman Jones, "Introduction", to idem (eds), Culture, Ideology and Politics: Essays for Eric Hobsbawm (London, 1982), p. ix. 
nationhood and nationalism, and engaged with them from the angle of their implications for historical materialism and socialist politics. However, despite this enduring preoccupation, and despite the widespread recognition that Hobsbawm is among the first rank of nationalism scholars, his encounter with the national question has not been systematically explored. ${ }^{3}$ In particular, the nexus between Marxism and nationalism in Hobsbawm's work has suffered undue neglect from those concerned with explicating the results of socialism's collision with national identity. ${ }^{4}$

Nationalism has constituted a key, according to some the key, condition for the production of modernity.' Consequently, national identity, it is commonly asserted, has trumped all rivals in the competition to fill humanity's need for meaning. ${ }^{6}$ Thus, against the expectations of Marx and Engels, national identity not class-consciousness has dominated the development of modern history, and nationalism not socialism has captured the imagination of the wretched of the earth. ${ }^{7}$ Marxism's defeat, it might be argued, required explanation. This is the task that Hobsbawm set himself from the early I 970 - a task that became more urgent as initial impediments to socialist advance were transformed into socialism's permanent derailment. ${ }^{8}$ Hence since the mid-I980s, and as an effect of Marxism's ruin, the

3. A partial exception is R. Beiner, "I989: Nationalism, Internationalism, and the NairnHobsbawm Debate”, Archives Européennes de Sociologie, 40 (1999), pp. I7 I-I 84. In histories of nationalism theory Hobsbawm's work is given due prominence, but these histories tend to be descriptive rather than analytic. For an exception, see U. Özkirimli, Theories of Nationalism: A Critical Introduction (New York, 2002), pp. I16-I27. An "anti-theoretical" critique of Hobsbawm's view of the national question can be found in A. Hastings, The Construction of Nationhood: Ethnicity, Religion and Nationhood (Cambridge, 1997), particularly pp. I-34.

4. Two exceptions, although neither, obviously, consider his latest work, are B. Jenkins and G. Minnerup, Citizens and Comrades: Socialism in a World of Nation States (London, 1984), pp. 64-85, and J.M. Blaut, The National Question: Decolonizing the Theory of Nationalism (London, I987), pp. I0I-I35.

5. E. Gellner, Nations and Nationalism (Oxford, I983).

6. B. O'Leary, "Ernest Gellner's Diagnoses of Nationalism: A Critical Overview, or, What is Living and What is Dead in Ernest Gellner's Philosophy of Nationalism”, in J.A. Hall (ed.), The State of the Nation: Ernest Gellner and the Theory of Nationalism (Cambridge, 1998), p. 40. For the same judgment from within the Marxist tradition, see G.A. Cohen, History, Labour, Freedom: Themes from Marx (Oxford, 1988), p. I46.

7. Even Marxists have admitted as much. See V. Kiernan, Marxism and Imperialism (Edinburgh, I974), p. I I7; R. Debray, "Marxism and the National Question”, New Left Review, I/ıos (1977), p. 35; and G. Therborn, "Dialectics of Modernity: On Critical Theory and the Legacy of Twentieth-Century Marxism”, New Left Review, I/2 Is (1996), p. 78. For Hobsbawm's own arguments along these lines, see, in particular, E. Hobsbawm, "What is the Workers' Country?", in idem, Worlds of Labour (London, 1984), p. 59. This article originally appeared in Saothar (Journal of the Irish Labour History Society), 8 (1982). Throughout this article reference will be made to the essay's republication in Worlds of Labour.

8. An indication of Hobsbawm's growing concern with the national question is "negatively proved" by two summations of his work - one published in 1979, the other in 1985 - which 
national question has increasingly displaced other concerns in his work the bandits of Spanish and Italian anarchism replaced by the bandits of Serbian and Croatian nationalism; socialist revolutionaries replaced by the revolutionaries of Scottish and Québécois separatism; the worlds of labour replaced by the world of nations. ${ }^{9}$ By the beginning of the new century, the national question assumed the central object of his thought. ${ }^{10}$

This article will provide a systematic analysis of Hobsbawm's conception of the relationship between socialism and nationalism in both his historical work and his political interventions. The article will begin with a brief description of Hobsbawm's "social being", the conditions, not of his own making, which shaped his thinking on nation and nationalism. ${ }^{\text {II }}$ The substance of the article will constitute an analysis of Hobsbawm's understanding of the national question grouped around three issues: (I) Are socialism and nationalism incompatible?; (2) Do the workers have a country?; and (3) What is the future of nationhood and nationalism? The article will end with a brief examination of Hobsbawm's assessment of the place of socialism and nationalism in our own time. To anticipate a conclusion, this article will argue that Hobsbawm's encounter with the national question has not only given rise to a formidable, though conflicted, analysis of nation and nationalism, but has also been central to his conception of socialism's past, present and future.

\section{WHAT IS HOBSBAWM'S COUNTRY? THE MAKING OF A MARXIST HISTORIAN}

What is Hobsbawm's country? Egypt, where his English-born father of Russian-Polish Jewish heritage worked for the British Empire, and where Hobsbawm was born in 1917? I2 $^{12}$ Austria, where his Viennese-Jewish mother was born and where Hobsbawm spent most of his childhood?

barely touch on his interest in nation and nationalism. See J. Cronin, "Creating a Marxist Historiography", pp. 87-109, and Kaye, The British Marxist Historians, pp. 13 I-166.

9. For Hobsbawm's early work on "primitive rebels" and "bandits", see Primitive Rebels (London, 1959) and Bandits (London, 1969). For his work on labour history, see Labouring Men: Studies in the History of Labour (London, 1964) and Worlds of Labour. For his contribution to the historiography of international communism, see Revolutionaries (London, 1973).

I0. Something in evidence throughout Hobsbawm, The New Century (London, 2000).

I I. This operation accords with Hobsbawm's own view. In the "Preface" to The History of Marxism, he argued: "Both the thought and practice of Marx and subsequent Marxists are the products of their times [and we might add, place], whatever their permanent intellectual validity or practical achievement." See E. Hobsbawm, "Preface" in idem (ed.), The History of Marxism, Volume I. Marxism in Marx's Day (Bloomington, IN, 1982), p. xii. The task of outlining Hobsbawm's "social being" has been made much easier by the recent publication of his autobiography, Interesting Times (London, 2003).

I2. This seems highly unlikely. For a brief account of his parents' years in Alexandria, see E. Hobsbawm, The Age of Empire, 1875-1914 (London, 1987), pp. I-3. 
Germany, whose language he first spoke and where he lived in his early teenage years before the death of his parents? ${ }^{13}$ England, where his uncle moved in the wake of Hitler's rise to power, and where Hobsbawm, who followed him, went to university? Great Britain, whose Communist Party Hobsbawm joined in 1936, in whose army he served during the years of World War II, and whose integrity he defended against the rise of fissiparous nationalisms in the I970s? ${ }^{\mathrm{I} 4}$ In truth, none fit. Hobsbawm is a Marxist historian who speaks and writes in at least four different languages (English, German, Italian, and French), who rejected the religion (Judaism) of his birth in favor of a secular ideology (socialism), and who throughout his life has lived in at least four countries (Austria, Germany, England, and the United States), felt at home in at least two others (Italy and France), but refers to none as his homeland. A rootless cosmopolitan, that most execrated figure of nationalist rhetoric, Hobsbawm does not have a country. ${ }^{\text {Is }}$ Like those members of the "trade guild" (history) to whom he has long felt a deep allegiance, he constitutes a "migrant bird, at home in arctic and tropic, overflying half the globe". ${ }^{16}$

It was not just his ancestry, the circumstances of his birth, and the involuntary geographical mobility of his early years that left him without a country. Rather Hobsbawm's nationless identity ${ }^{17}$ was a direct consequence of his commitment to that internationalist ideology par excellence, Marxism, a commitment that mushroomed in the Berlin of the early 1930s. ${ }^{18}$ This was not an unlikely place for such an identity to develop,

I3. This would perhaps be the most likely candidate, at least for linguistic nationalists.

I4. Some have made this claim. See T. Nairn, Faces of Nationalism: Janus Revisited (London, 1997), p. 42; Jenkins and Minnerup, Citizens and Comrades, p. 77; and P. Anderson, Spectrum (London [etc.], 2005), p. 292.

I5. As Tom Nairn has suggested, although the internationalist speaks "from nowhere in particular", he or she is no freer of particularity than the nationalist - internationalism is a belief system of the order of nationalism, bias inheres in both. See T. Nairn, "Internationalism and the Second Coming”, in G. Balakrishnan (ed.), Mapping the Nation (London [etc.], I996), p. 268. 16. See Hobsbawm, Interesting Times, p. 4Is. If there is one "imagined community" that Hobsbawm belongs to it is perhaps the "imagined community" of historians. For his account of this community in his lifetime, see Interesting Times, pp. 282-297. Hobsbawm taught at Birkbeck College from 1947 to I982, and then at the New School for Social Research from 1984 to 1997 .

I7. The word "identity" is consistently misused and misunderstood according to Fredrick Cooper and Rogers Brubaker. See F. Cooper (with R. Brubaker), "Identity", in F. Cooper, Colonialism in Question: Theory, Knowledge, History (Berkeley, CA, 2005), pp. 59-90. I use the term in the sense (described by Cooper and Brubaker, p. 65) of "a core aspect of [...] selfhood or a fundamental condition of social being".

I 8. Horace B. Davis has suggested that "Internationalism ... is the essence of Marxism". See H.B. Davis, Toward a Marxist Theory of Nationalism (New York [etc.], I978), p. I 8. Hobsbawm later characterized his initial encounter with Marxism as "liberating". See E. Hobsbawm, "What Do Historians owe Karl Marx?", in idem, On History (London, 1997), p. 194. This article was earlier published in Diogenes, 64 (1969), pp. 37-56. Reference to the essay in this article will be to its republication in On History. 
especially not for a Jew. As the Weimar Republic descended into crisis, undermined by the ultra-nationalist and anti-Semitic politics of Hitlerite fascism, Jews increasingly found themselves constituted as Germany's foundational "Other". In such circumstances, rather than an "opiate of the intellectuals", in Raymond Aron's acerbic phrase, Marxism, for many (German) Jews, appeared a political necessity. As Hobsbawm later recalled: "We [Jews] simply choose a future, rather than no future, which meant revolution. But it meant revolution not in a negative sense but in a positive sense: a new world rather than no world." 19 For Hobsbawm, that implied the global transformation of a system of production that had produced endemic poverty, war, and fascism - in short, a new world required world revolution. In the early i930s this was not a quixotic Marxist fancy. ${ }^{20}$

According to Age of Extremes, the twentieth century "cannot be understood without the Russian revolution and its direct and indirect effects". ${ }^{21}$ The same might be said of Hobsbawm. ${ }^{22}$ For him, as for so many other west European Marxists in the I930s, the Soviet Union and its project of world revolution constituted an already existing alternative to capitalism and fascism, to an old order which events seemed to prove was no longer viable. In this vision, where Nazism offered national socialism as a salve to capitalism's ills, the Soviet Union offered the socialist Cosmopolis free from poverty and want; where Nazism promised eternal war between races, the Soviet Union promised universal peace; and where Nazism exalted the supremacy of the German people and the irrational, the Soviet Union exalted universal equality and reason. In a world unhinged by economic and political collapse, it was an appealing vision.

For the young Hobsbawm it was overwhelming: there was only one means to overcome the seemingly interlaced absurdities of capitalism and fascism - worldwide socialist revolution, the project begun by the Bolshevik seizure of power in October i917. Thus when Hobsbawm became a communist in the Berlin of 1932 , beginning an association which would last until the demise of the Soviet Union in the early i990s, he was not only endorsing the view that communism offered a universal alternative to economic catastrophe and fascism. He was also affirming

19. Hobsbawm, "Intellectuals and the Class Struggle" in Revolutionaries, p. 300. Italics appear in the original. In Interesting Times, p. 62 he claimed that most militant Zionists were socialists of one sort or another, "mostly of various Marxist convictions".

20. See Hobsbawm, "Intellectuals and the Class Struggle", p. 300. In addition, see J. Saville, "The Communist Experience: A Personal Appraisal", in R. Miliband and J. Saville (eds), The Socialist Register 1991 (London, 199I), p. 3, and R. Samuel, "The Lost World of British Communism", New Left Review, I/I 54 (1985), p. 38.

21. E. Hobsbawm, The Age of Extremes: The Short Twentieth Century, 1914-I99I (London, I994), p. 84 .

22. See Hobsbawm, Interesting Times, p. 217. 
that socialist revolution was his homeland and that the sole community worth imagining or belonging to was one that included all the peoples of the world. ${ }^{23}$ The memory of this moment would leave a deep imprint on his life; indeed Hobsbawm's intellectual and political contributions would be insensible without it.

When Hobsbawm left Germany for England in 1933, then, he had already committed himself to a set of beliefs that would endure and been gripped by what he later characterized as "that typical twentieth-century passion, political commitment". ${ }^{24}$ Like Germany, his new home had also been rocked by the almost worldwide crisis of capitalism. ${ }^{25}$ However, unlike Weimar Germany, England did not give birth to a mass revolutionary workers' movement. Thus, although Hobsbawm remained a communist during the initial years of his stay in London, the circumstances made it hard to imagine life as a professional revolutionary, at that time his preferred vocation. Having escaped Berlin shortly after the rise of Hitler, in England he would explore Marxism through books rather than the immediate struggle against fascism as he had in the last months of his life in Berlin. With the memories of those times still "spiritually" present, it was during a three-year hiatus from politics before he began university that the disciplinary appellation of the identity Marxist historian was born. ${ }^{26}$

The disciplinary and the political aspects of Hobsbawm's identity coalesced in 1936 when he went to Cambridge to study history and joined the Communist Party of Great Britain (CPGB). ${ }^{27}$ Active in the student communist milieu at Cambridge in the late I930s, a time when the ranks of communism were swelled by the rise of fascism, the Spanish Civil War, and the politics of the Popular Front, Hobsbawm spent the war years fulfilling a number of banal duties in the British army, perhaps barred from more active involvement by his Bolshevik politics. ${ }^{28}$ The experience of the Popular Front period and the "People's War", however, constituted crucial moments in Hobsbawm's political formation, moments which would in part determine not just the character of his Marxist

23. Ibid., p. I37. Also see Samuel, “The Lost World of British Communism”, pp. Io and I I.

24. Hobsbawm, Interesting Times, p. I I.

25. Ibid., p. 46.

26. Ibid., pp. $95-98$.

27. For the history of the CPGB during this period, see A. Thorpe, The British Communist Party and Moscow, 1920-1943 (London, 200I), and M. Worley, Class Against Class: The Communist Party in Britain between the Wars (London, 2002). But note the critique of these histories in J. McIlroy and A. Campbell, “Nina Ponomareva's Hats': The New Revisionism, the Communist International, and the Communist Party of Great Britain, 1920-1930", Labour/Le Travail, 49 (2004), pp. I 47-1 88.

28. This suggestion is Hobsbawm's. See his Interesting Times, p. I 54. On Hobsbawm's own experience of communism at Cambridge, see "Interview with E.J. Hobsbawm", Radical History Review, I9 (1978-1979), pp. III-I3I. 
politics but also his understanding of the potential value of patriotism to international socialism. Allowing reconciliation between communists, national social democrats and conservative patriots, the Popular Front against fascism provided Hobsbawm with crucial strategic insights into the way socialism could be advanced in conditions where revolution had been either stalled or temporarily defeated. ${ }^{29}$ Indeed, popular resistance to fascism was central to the political and intellectual development of many of the members of the Communist Party Historians' Group (CPHG), of which Hobsbawm was a prominent member throughout the late I940s and I950s..$^{\circ}$ Developments in British communism in the immediate period after 1945 - the "British road to socialism" - were also important in this respect. ${ }^{31}$ This period in British communism's history constituted a self-conscious attempt by the CPGB to extend the strategy of the Popular Front into the immediate postwar years, aligning the cause of national reconstruction to international socialism; ${ }^{32}$ it also overdetermined the tradition of British Marxist historiography, a tradition which would have a disproportionate influence on the development of Anglo-American intellectual thought in the last half of the twentieth century. 33

Thus, Hobsbawm's commitment to international communism remained intact through and immediately after World War II. More surprisingly, it remained intact throughout I956 - that year of the revelation of Stalinism's crimes and the Soviet invasion of Hungary - as well. Hobsbawm's decision to remain a member of the CPGB is surprising because so many other members of the CPHG, including E.P. Thompson, John Saville, Christopher Hill, and Victor Kiernan, believed it necessary, for Marxism's good,

29. E. Hobsbawm, "Fifty Years of People's Fronts", in idem, Politics for a Rational Left: Political Writing, I977-1988 (London, I989), p. 107.

30. On the CPHG, see E. Hobsbawm, "The Historians' Group of the Communist Party”, in M. Cornforth (ed.), Rebels and their Causes: Essays in Honour of A.L. Morton (London, 1978), pp. $2 \mathrm{I}-48$, and B. Schwarz, “The People' in History: The Communist Party Historians Group, 1946-1956", in R. Johnson et al., Making Histories: Studies in History Writing and Politics (London, 1982), pp. 44-95. For an account of the relationship between the CPHG and the national question, see D. Renton, "Studying Their Own Nation without Insularity? The British Marxist Historians Reconsidered”, Science and Society, 69 (2005), pp. 559-579. Also consider P. Blackledge, Reflections on the Marxist Theory of History (Manchester, 2006), pp. 82-86.

3r. On this period in the CPGB's history, see D. Childs, "The Cold War and the 'British Road', 1946-53", Journal of Contemporary History, 23 (1988), pp. 55 I-572.

32. For the immediate pre-history of the CPGB's attempt to make communism compatible with the nation, see G. Roberts, "Limits of Popular Radicalism: British Communism and the People's War, I94I-1945”, Chronicon, I:3 (1997), pp. I-i 9 .

33. On the tradition of British Marxist historiography, see Kaye, The British Marxists, and $\mathrm{H}$. Kaye, The Education of Desire: British Marxists and the Writing of History (London [etc.], 1992). For the tradition's influence on the development of history and cultural studies, see D. Dworkin, Cultural Marxism in Postwar Britain: History, the New Left and the Origins of Cultural Studies (Durham [etc.], 1997). 
to leave. ${ }^{34}$ According to Hobsbawm's autobiography, he stayed because he believed it was important to remain true to the memory of those communists who had, as E.P. Thompson said, put "their bodies between fascism and freedom". ${ }^{35}$ Moreover, formed in the immediate prelude to Hitler's rise to power, he maintained that it was simply more difficult for him to leave than for those who had joined somewhere else and at some other time. In this way, Hobsbawm argued, his political formation in the shadow of the Weimar Republic's imminent collapse - "when being a communist meant not simply fighting fascism but the world revolution" 36 - constituted an overwhelming factor in his decision to remain within what he would later call the "universal church" 37 of communism..$^{38}$

However, there were others within the CPGB equally committed to the memory of those who laid their lives down for anti-fascism, and equally resolved to avoid the characteristic anti-communist terminus common to those Cold War times, who thought it necessary to leave the party in 1956. For some, including some who had dodged fascist bullets, that was what I956 was about. For them, remaining true to the memory of the struggle against fascist barbarism precisely meant renouncing Soviet communism. Hobsbawm did not interpret 1956 this way. It is difficult to imagine, however, that he was only prevented from doing so "out of loyalty to a great cause and to all those who had sacrificed their lives for it". ${ }^{39}$ This might be true in retrospect but it was not necessarily true at the time, as Hobsbawm himself has admitted.

Nonetheless, although what was true at the time can only be a matter of speculation, it might be noted that Hobsbawm's continuing association with international communism allowed him access to an international milieu characterized by comradeship and intellectual fraternity, a milieu that would have been denied him had he renounced communism in 1956. For example, in Primitive Rebels he acknowledged the help and support his path-breaking research on "archaic" forms of social movement had received from various functionaries and officials in the Italian Communist party. From this it might be concluded that his politics were not always an obstruction to his career as a scholar..$^{\circ}$ In other words, in some countries,

34. This should not imply that Hobsbawm was unsympathetic to communist dissent. He contributed to the communist dissident press, and signed his name to a dissident letter that appeared in Tribune and the New Statesman in 1956.

35. E.P. Thompson, The Fascist Threat to Britain (London, 1947) p., I6, cited in B.D. Palmer, E.P. Thompson: Objections and Oppositions (London, 1994), p. 50. For Hobsbawm's explanation for why he stayed, see his Interesting Times, pp. I4I and 217-218.

36. Ibid., p. 217.

37. Idem, Age of Extremes, p. 73.

38. See E. Hobsbawm, "The Emancipation of Mankind - Eric Hobsbawm interviewed by Peter Glotz", in idem, Politics for a Rational Left, p. $20 \mathrm{I}$.

39. Idem, The New Century, p. I 59.

40. Idem, Primitive Rebels, p. vi. 
at least, his communist party membership operated as a "code of entry"4I to intellectual circles, places and, in some cases, institutions which would have otherwise been sealed off to him.

Whatever his individual reasoning, Hobsbawm's resolution that international socialism was best served within the CPGB did not prevent him being critical of actually existing socialism or from expressing fraternity, though limited, with other socialist groupings. For example, his CPGB membership was no obstacle to his participation in various projects of the British New Left, although he was always unsympathetic to socialist humanist politics. ${ }^{42}$ Nonetheless, he contributed pieces to The New Reasoner, E.P. Thompson and John Saville's journal of communist dissent, and to the New Left Review, house journal of the New Left, in the I960s. ${ }^{43}$ This, in some ways, connects with his later statement that he and those who left the CPGB in 1956 were fighting for the same things. ${ }^{44}$

However, in reality, Hobsbawm remained unconvinced by the practical political benefits of such projects, something reflected in his contribution to their purpose - academic not political.45 In fact, following 1956 Hobsbawm mostly quit political activism of any type..$^{46}$ After the CPGB's failure to reform itself in the wake of the Soviet invasion of Hungary, Hobsbawm's socialist activism was confined to history writing, involvement with short-term political protest movements, including those against nuclear weapons and the Vietnam War, and to interventions over the future of the Labour Party in the late I970s and early I980s..$^{47}$ Embedded

4I. The phrase is Hobsbawm's and can be found in Interesting Times, p. 326.

42. Unfortunately, in his autobiography his originally friendly criticism of the New Left descended into derision. See Hobsbawm, Interesting Times, pp. 2 I I-2 I 2.

43. For an outline of The New Reasoner's history, see B.D. Palmer, "Reasoning Rebellion: E.P. Thompson, British Marxist Historians, and the Making of Dissident Political Mobilization", Labour/Le Travail, 40 (2002), pp. I87-216.

44. As he later remarked about his relationship with the communist dissidents: "Those of us who stayed stood for the same things, were fighting for the same things". See E. Hobsbawm, "I 956 ", Marxism Today, (November 1986), p. 2 I. For more on 1956 and the CPGB, see J. Saville, "E.P. Thompson, the Communist Party and 1956", in J. Saville and C. Leys (eds), Socialist Register 1994: Between Globalism and Nationalism (London, 1994), pp. 20-3 I.

45. See E. Hobsbawm, "Dr Marx and the Victorian Critics", New Reasoner, I (1957), pp. 29-39; idem, "Hyndman and the SDF", New Left Review, I/ı (I96I), pp. 69-72; and idem, "Parliamentary Cretinism", New Left Review, I/I 2 (I96I), pp. 64-66.

46. Hobsbawm, Interesting Times, p. 2 I I.

47. Hobsbawm's political activism is recounted throughout Interesting Times. For his intervention, largely, he claims, unintended, over the future of the Labour Party in the late I 970 s and early I 980 , see his essay "The Forward March of Labour Halted?", Marxism Today, I 2:9 (1978), pp. 279-286. This essay was later republished in M. Jacques and F. Mulhern (eds), The Forward March of Labour Halted? (London, I98I), pp. I-I9. In the same edition see Hobsbawm's "Response" to the debate his article started, and his "Observations on the Debate", pp. 64-7I and pp. I67-I 82 respectively. For a later account of his role in the debate, see his Interesting Times, pp. 263-272. Note the critique of this account in Anderson, Spectrum, pp. 289-290. 
in the academic world from the late I940s (he received his first academic post at Birkbeck College, London University in I947), Hobsbawm mostly eschewed the political activism that was characteristic of the "way of life" of other contemporary socialist historians.

Hobsbawm's alienation from political practice is, as he himself admitted, arresting, not only given the trajectories of figures like E.P. Thompson and Raymond Williams, with whom he might be compared, but also because he claimed to have been gripped by political commitment from an early age..$^{8} \mathrm{~A}$ historian who happened to be a socialist rather than a socialist-historian, Hobsbawm, as a chapter in Interesting Times suggests, was a "watcher in politics". This sense of himself as a "watcher in politics" was reflected in his "mode of writing". Whether in his historical writings or his historically informed political journalism, Hobsbawm wrote from an Olympian perspective, a perspective that perhaps came easily and appropriately to a figure who was consistently forced to live in between homes. Deracination, however, gave rise not just to a sense of political detachment, but also to a disavowal of human agency, whether in history or everyday political practice. Rather than seek out those alternative "practices of possibility" or "resources of hope" that other socialists saw as crucial to socialism's future after 1956, Hobsbawm was a Marxist historian who was primarily interested in interpreting the world, not changing it. A form of historical practice that was predominantly concerned with patterns and structures was unlikely to give rise to new forms of socialist praxis - there was a (political) world of difference in tone between The Making of the English Working Class and The Age of Revolution. 49

By some time during the i96os (The New Century suggested as early as I956), ${ }^{\circ}$ Hobsbawm believed that the socialist project was doomed. ${ }^{51}$ His awareness of Marxism's historic crisis - what he called the "forward march of labour halted" - came relatively early. Strangely enough, although not from the perspective of classical Marxism, intimations of communism's absolute defeat for Hobsbawm appeared most clearly in the capitalist West not in the communist East. Of course Hobsbawm was cognizant of socialism's travails east of the Elbe, signified by the dates 1956 and I968,

\footnotetext{
48. Hobsbawm, Interesting Times, p. 263.

49. More often than not Hobsbawm and Thompson are grouped together in the category "British Marxist historians". This grouping needs to be considered with care. Hobsbawm in Interesting Times pointed to significant differences when he (again) questioned the value of Thompson's critique of Althusserian Marxism. See Interesting Times, p. 215. Further divergences between Hobsbawm and Thompson are pointed to in an unpublished paper by Bryan Palmer on Hobsbawm's historiographical achievements. I thank the author for allowing me to read this unpublished piece. Also see Palmer, "Reasoning Rebellion", pp. i87-216.

50. Hobsbawm, The New Century, p. I59.

5. As Hobsbawm later admitted in "Goodbye to All That", in R. Blackburn (ed.), After the Fall: The Failure of Communism and the Future of Socialism (London, 1991), p. I I6.
} 
the Sino-Soviet split, and the wretched condition of socialism's stateplanned economies. However, he believed that once it became clear that the working class in advanced capitalist societies had not only deserted revolution but was structurally incapable of perpetuating it, the project of world revolution had to be abandoned. If this wasn't problem enough, he caught early sight of another potentially insurmountable obstruction to socialist progress. In the late ig6os there appeared a force in western Europe that socialists (and many liberals) had claimed to have already reckoned with: nationalism. ${ }^{52}$ Its return, Hobsbawm felt at the time, and later admitted, would prove fatal to the "universalism" of the historic Left. .3

\section{THE JOURNEY AND THE DETOUR: SOCIALISM AND NATIONALISM}

Despite the Communist Manifesto's claim that national particularism would be swept away by the establishment of a global market, Marxists in the twentieth century were forced to come to terms with capitalism's world of nations and its consequences for Marxist theory and socialist practice. How could an ostensibly cosmopolitan ideology operate within a world populated by nationalisms? ${ }^{24}$

52. For a brief history of this moment, consult B. Anderson, "Introduction", in Balakrishnan, Mapping the Nation, pp. I-I6.

53. E. Hobsbawm, "Identity Politics and the Left", New Left Review, I/217 (1996), pp. 38-47. On the "universalism" of the Left, see N. Lazarus, S. Evans, A. Arnove, and A. Menke, "The Necessity of Universalism", Differences, 7 (1995), pp. 75-145. The traditional Left's "universalism" is most often read today as a cover for "Eurocentrism". For a rejection of this argument, see P. Bhanu Meta, "Cosmopolitanism and the Circle of Reason", Political Theory, 28:5 (2000), p. 63.

54. The question of whether Marxism should be properly represented as a cosmopolitan or an internationalist ideology is fraught. Most Marxists, as Alejandro Colás has suggested, have preferred "socialist internationalism" as a description of their politics, although he argues that "socialist internationalism" is a species of "cosmopolitanism". See A. Colás, "Putting Cosmopolitanism into Practice: The Case of Socialist Internationalism”, Millennium: Journal of International Studies, 23 (1994), pp. 519 and 5 I 5 . Other commentators have preferred to make a clear distinction between "internationalism" and "cosmopolitanism". This is the position of Tim Brennan in his "Cosmopolitanism and Internationalism" New Left Review, 7 (200I), p. 77: "The cosmopolitan ideal envisages less a federation or coalition of states than all-encompassing representative structure in which delegates can deliberate on a global scale. By contrast, internationalism seeks to establish global relations of respect and cooperation, based on acceptance of differences in polity as well as culture." Thus the distinction between "internationalism" and "cosmopolitanism" is seen to resolve around the nation state. Internationalism, as Perry Anderson and others have suggested, is premised on the "primacy" of the nation state; cosmopolitanism is premised on the transcendence of the nation-state system. See P. Anderson, "Internationalism: A Breviary", New Left Review, I4 (2002). Following Anderson, Robert Stuart has suggested "Cosmopolitanism is opposed to nationalism; 'inter' nationalism is founded upon it". See R. Stuart, Marxism and National Identity: Socialism, 
Marxists have offered a number of solutions to socialism's national dilemma. 55 In one view (associated with the thought of Rosa Luxemburg) it was argued that Marxists should have nothing to do with nationalism because it undermined class-consciousness and diverted the proletariat from their "true" class interest. ${ }^{56}$ In another view (associated with Leninism), it was argued that Marxists, under certain circumstances, could marry social and national liberation to the benefit of world socialism. 57 Here, armed with "rights", and divided into "oppressor" and "oppressed", nations were figured as deserving of freedom and consequently of socialist support. ${ }^{58}$ However, beyond this instrumental nationalism, other Marxists claimed that nationalism (even national separatism) was a necessary detour on the journey toward socialism. In the discourse of English-speaking Marxism, this contention was most famously advanced by Tom Nairn in the context of the rise of separatist nationalisms in Britain in the last half of the twentieth century. 59 Nairn's argument in favor of "neo-nationalism" prompted Hobsbawm's reflections on the problem of nationalism for socialist politics in the late I970s.

Could Marxists become nationalists as socialists such as Nairn in his The Break-Up of Britain suggested they must? Not according to Hobsbawm. For him, Marxists could be nationalists neither in theory nor in practice. ${ }^{60}$ They could not be nationalists in theory, he argued, because nationalism

Nationalism, and National Socialism during the French Fin de Siècle (New York, 2006), p. I88, n. I. Marx himself, according to James Petras, made a distinction between "internationalism" and "cosmopolitanism", arguing that the former would constitute a stage on the way to the latter. See J. Petras, "Marx and Engels on the National Question", Review of Politics, 33 (I97I), p. 8I I. Marx's politics might then be described as "cosmopolitanism", his projected end-state characterized as a "worldwide socialist community" which had done away with nation states. 55. For a general overview of debates among Marxists on the national question, see M. Löwy, "Marxism and the National Question", New Left Review, I/96 (1975), pp. 8I-Io0, and A.W. Wright, "Socialism and Nationalism", in L. Tivey (ed.), The Nation State (Oxford, 1981), pp. I $45-170$.

56. On Luxemburg's "proletarian internationalism”, see J-H. Lun, "Rosa Luxemburg and the Dialectics of Proletarian Internationalism and Social Patriotism”, Science and Society, 59 (1995I996), pp. 498-530.

57. For an account of the Leninist view of the relationship between national liberation and world socialism, see W. Connor, The National Question in Marxist-Leninist Theory and Strategy (Princeton, NJ, 1984), pp. 28-42.

58. Such was the ubiquity of this view among Marxists in the twentieth century that one historian could claim by the 1980 s that it was "difficult to remember that internationalism was once a cornerstone of radical social thought". See S.E. Bronner, Rosa Luxemburg: A Revolutionary For Our Times (New York, 1987), p. 17.

59. T. Nairn, The Break-Up of Britain: Crisis and Neo-Nationalism (London, 1977). The book has been recently republished (on the twenty-fifth anniversary of its original publication) with a new introduction. See Nairn, The Break-Up of Britain (Melbourne, 2003).

60. Marxists [...] and historians. For his argument that historians can not be nationalists, see E. Hobsbawm, "The Historian between the Quest for the Universal and the Quest for Identity", Diogenes, I68, 42:2 (1994), pp. 51-63. 
was irrational and sustained by a set of myths which Marxists should refuse because they bore no relation to historical reality - a set of myths bankrolled by the premise that nations constitute the "a priori eternal data of human society". ${ }^{61}$ Nor could Marxists be nationalists in practice, Hobsbawm contended, because "nationalism by definition subordinates all other interests to those of its specific nation" ${ }^{62}$ In his view, nationalism undermined two central axioms of Marxist politics: that nation states are fractured by class and that nationalism constituted a form of class collaboration antagonistic to socialism. In addition, he claimed that nationalism was antithetical to the Marxian vision of "some form of association or organizational union of nations, possibly preceding [...] the eventual dissolution of national into global or generally human culture". ${ }^{63}$ Nationalism, according to Hobsbawm, blotted out the Marxist horizon of a universal socialist culture. ${ }^{64}$

For Hobsbawm, the correct Marxist attitude toward nationalism in practice was "not unsympathetic, but contingent and not absolute". ${ }^{5}$ "The fundamental criterion of Marxist pragmatic judgment", he declared, "has always been whether nationalism as such, or any specific case of it, advances the cause of socialism; or conversely, how to prevent it from inhibiting its progress; or alternatively, how to mobilize it as a force to assist its progress". ${ }^{66}$ From this strategic parti pris Hobsbawm damned Nairn's political prescriptions in The Break-Up of Britain: national separatism would not help socialism dig capitalism's grave. Hence although Marxists were "neither for nor against independent statehood for any nation" 67 in principle, and did not maintain the a priori view that big nations were to be preferred to small ones, in his opinion there was no good reason for supposing that the break-up of Britain (or any other existing state) would advance international socialism. To Hobsbawm's mind the establishment of national states as such could not be transformed into an agent producing socialist change either in addition to or as a replacement for the "Marxian historic mechanism" - which, he argued,

6r. E. Hobsbawm, "Reflections on 'The Break-Up of Britain”, New Left Review, I/ros (1977), p. Iо. For a more recent claim that nationalism is "irrational", see A. Vincent, "Power and Vacuity: Nationalist Ideology in the Twentieth Century", in M. Freeden (ed.), Reassessing Political Ideologies: The Durability of Dissent (London [etc.], 2001), pp. 139-I40.

62. Hobsbawm, "Reflections on 'The Break-Up of Britain", p. 9.

63. Ibid., 4. For a similar view, consult R.N. Berki, "On Marxian Thought and the Problem of International Relations”, World Politics, 24 (197I), pp. 97-99.

64. The vision of an "association or organizational union [of nations]" is internationalist; the "dissolution of national into global or general culture" is cosmopolitan. See Hobsbawm, "Reflections on 'The Break-Up of Britain", p. ıо. For the distinction between "internationalism" and "cosmopolitanism" see n. 54 .

65. Hobsbawm, "Reflections on 'The Break-Up of Britain'”, p. 8.

66. Ibid.

67. Ibid., p. 9. 
"includes the formation of some nation-states as an essential part of capitalist development, and a crucial strategic role for some national movements; but not what nationalism requires, namely a charter for any such state or movement". ${ }^{68}$ Painting nationalism red, Hobsbawm warned, would distort socialist ideology and obliterate the "science" of Marxist theory. ${ }^{69}$ With Nairn, the detour, he alleged, had become the journey.

It was transparent, Hobsbawm suggested, why Marxists had championed nationalism in the past. The criteria here was the advancement of bourgeois society - that is, Marx, for example, had supported particular nationalisms to the degree that they could be understood as promoting the development of the capitalist mode of production. ${ }^{70}$ But this "nationalism" was not nationalist in the current sense of that term, Hobsbawm argued, because "it did not envisage a world of nation-states irrespective of size and resources" - it held that only a limited number of states were viable on certain economic, military and political criteria - and because it "de facto abandoned the national homogeneity of most accepted 'nation-states"' $7^{\mathrm{I}}$ Hobsbawm also conceded the strategic value of marrying national and social liberation during the anti-fascist period and in the context of imperialism..$^{72}$ In both cases, he believed, nationalism could be understood as a progressive force facilitating rather than inhibiting socialist advance.

But in his commentary on The Break-Up of Britain, Hobsbawm offered no contemporary example of nationalism that Marxists could champion to international socialism's advantage, an assessment that drew the ire of those Marxists still committed to the project of anti-imperialist nationalism. ${ }^{73}$ Indeed Hobsbawm maintained that even in those situations

68. Ibid., p. I2. Italics in the original.

69. Ibid., p. 22.

70. Ibid., p. 4. For more on Marx's support for certain nations in the nineteenth century, see E. Benner, Actually Existing Nationalism: A Post-Communist View from Marx and Engels (Oxford, 1997), pp. I44-I58; and M. Forman, Nationalism and the International Labor Movement: The Idea of the Nation in Socialist and Anarchist Theory (University Park, PA, I998), pp. $4^{8-5 \text { I. }}$

7r. Hobsbawm, “Reflections on 'The Break-Up of Britain'”, p. 4. For Hobsbawm's understanding of viability, see his The Age of Capital, I848-1875 (London, I975), pp. I03-I2I.

72. Hobsbawm, "Reflections on 'The Break-Up of Britain", p. Io. For more on (British) Marxism's reconciliation with nationalism in the anti-fascist period and beyond, consult $\mathrm{S}$. Howe, "Labour Patriotism, 1939-83", in R. Samuel (ed.), Patriotism and the Making and Unmaking of British National Identity, vol. I History and Politics (London, I989), pp. I 27-I 39. 73. Hobsbawm, "Reflections on 'The Break-Up of Britain”, pp. i I and 22. For the argument that Hobsbawm's assessment of nationalism was insensitive to national liberation in the colonial and neo-colonial world, see Blaut, The National Question: Decolonising the Theory of Nationalism, p. ror. Blaut's judgment, it should be noted, overlooks two of Hobsbawm's earlier essays, "Vietnam and the Dynamics of Guerilla War", and "Civilian versus Military in Twentieth Century Politics", originally published in 1965 and 1967 respectively, which were reprinted in Revolutionaries. The 1967 essay concluded: "The tragedy of the underdeveloped world in the I950s and I960s was that the United States and its allies, when it came to the point, 
where socialists had supported national movements previously such a strategy was not beyond challenge. There were few cases, he lamented, where "Marxists succeeded in establishing or maintaining themselves as the leading force in their national movement". ${ }^{74}$ More often "they [Marxists] have either become subordinates to, or been absorbed by, or pushed aside by non-Marxist or anti-Marxist nationalism". ${ }^{75}$ In the end, Hobsbawm suggested, there could be no amicable marriage between Marxism and nationalism - the relationship always ended in divorce with nationalism running away with the family property. In such circumstances, he concluded, "the Luxemburgist case is not entirely unrealistic" ${ }^{76}$

Shortly after publishing his critique of The Break-Up of Britain Hobsbawm overturned this view. In the context of Thatcherism's ascendancy, he provided a strategic explanation for why socialists must embrace "national patriotism" for socialism's good.77 Indeed, given the

preferred 'order' to 'progress' - Mobutu to Lumumba, Ky or Thieu to Ho-Chi-Minh, any Latin General to Fidel Castro." This is an order of sympathies consistent with sensitivity to anticolonial liberation. See Hobsbawm, "Civilian versus Military in Twentieth Century", Revolutionaries, p. I91. In connection with this it should be remembered that Hobsbawm's book Bandits had ranged across Asia and Latin America, sympathetically portraying figures and movements otherwise ignored by international historiography at the time of the book's publication in the r960s.

74. Hobsbawm, "Reflections on 'The Break-Up of Britain”, pp. Io-II. For a more recent elucidation of this argument, see S. Makdisi, C. Casarino, and R. Karl, "Introduction: Marxism, Communism and History”, in Makdisi et al. (eds), Marxism beyond Marxism (New York, 1996), I-I3; and F. Jameson, "Globalization and Strategy", New Left Review, II/4 (2000), pp. 49-68. 75. Hobsbawm, "Reflections on 'The Break-Up of Britain", p. i I.

76. Ibid., I 3. For an explication of the "Luxemburgist" solution to the national question, see Forman, Nationalism and the International Labor Movement, pp. 83-94. For an argument that Luxemburg deserves to be taken seriously by scholars of nationalism today, see J. Cocks, "From Politics to Paralysis: Critical Intellectuals Answer the National Question”, Political Theory, 24:3 (1996), pp. 54-56. Benedict Anderson's Imagined Communities: Reflections on the Origin and Spread of Nationalism (first published in 1983) was partly written as a critique of Hobsbawm's ("Luxemburgist") position in his debate with Tom Nairn over "the break-up of Britain" as Anderson later admitted in an "Afterword" to the 2006 revised edition of Imagined Communities. See B. Anderson, Imagined Communities: Reflections on the Origin and Spread of Nationalism (London [etc.], rev. edn 2006), pp. 208-209. In the same "Afterword” Anderson also claimed that an original inspiration behind the writing of Imagined Communities was to counter the "Eurocentrism" of Hobsbawm's theory of nationalism.

77. E. Hobsbawm, "Falklands Fallout", in Hobsbawm, Politics for a Rational Left, pp. 51-62. The article originally appeared in Marxism Today in January 1983 . At this time Hobsbawm was on the editorial board of the CPGB periodical. See Kaye, The British Marxist Historians, p. I64. Hobsbawm did not make a distinction in "Falklands Fallout" between patriotism and nationalism. Indeed in his unusual formulation "national patriotism" he appeared to conflate the two. For an argument that nationalism and patriotism should be distinguished, see M. Viroli, For Love of Country: An Essay on Patriotism and Nationalism (Cambridge, 1995), pp. I-I7. Viroli castigates Hobsbawm's elision of patriotism and nationalism on p. I, n. I - although he focuses on Hobsbawm's elision of these phenomena in his Nations and Nationalism since 1780. 
New Right's successful exploitation of the "national interest" during the Falklands conflict, he argued that socialism must be reconciled to nationalism rather than constitute its ideological antithesis. A product of his newly found conviction that "the national" constituted the necessary ground of all politics, ${ }^{78}$ Hobsbawm believed that Marxism had to appropriate national identity for socialist ends. In the early I980s, along with Stuart Hall and other figures associated with the CPGB journal Marxism Today, Hobsbawm thus urged socialists to agitate for a vision of socialism that was not antagonistic to national belonging. ${ }^{79}$ Marxists, Hobsbawm argued, might be right to be wary of patriotism because it obliterated class-consciousness and was traditionally associated with, and better adapted to, a politics of reaction. ${ }^{80}$ But, for him, it was precisely because of this that they needed to meld their class politics with national patriotism. ${ }^{81}$ The detour, for Hobsbawm, was now an intrinsic part of the journey.

Consequently in this register, nationalism was not necessarily a barrier to socialist advance. The proof of the pudding, Hobsbawm contended, had been in the eating. In the mid-Victorian period Chartists had married a "militant class-consciousness" to national chauvinism; ${ }^{82}$ through the Popular Front strategy the Comintern had allied patriotism to socialism's anti-fascist cause; and following the end of World War II, communist parties in Italy and France had mobilized the national tradition for socialist ends. ${ }^{83}$ Each case had met with some success, and part of that success, Hobsbawm alleged, rested on the ability of socialists to "wrest away national traditions from the bourgeoisie, to capture the national flag so long waved by the right". ${ }^{84}$ None of this success, he claimed, proved that

78. For an explication of this point, see M. Freeden, "Is Nationalism a Distinct Ideology?", Political Studies, 46 (1998), pp. 748-765; and P. Lekas, "The Supra-Class Rhetoric of Nationalism", East European Quarterly, 30 (1996), p. 275.

79. For an account of Hobsbawm's Marxism Today period, see H. Pimlott, "From 'Old Left' to 'New Labour'? Eric Hobsbawm and the Rhetoric of 'Realistic Marxism'”, Labour/Le Travail, 56 (2005), pp. $175-198$.

80. Hobsbawm, "Falklands Fallout", p. 58.

81. Ibid.

82. For an argument that class reinforced nationality, and nationality class, in Britain in the nineteenth and twentieth centuries, see J. Hinton, "Voluntarism and Jacobinism: Labor, Nation, and Citizenship in Britain, 1850-1950", International Labor and Working Class History, 48 (1995), pp. 68-90.

83. The examples are outlined in Hobsbawm, "Falklands Fallout", pp. 58-59. For this general argument reinforced with particular reference to the Popular Front period, see Hobsbawm, "Fifty Years of Peoples' Fronts", pp. 103-i i7.

84. Hobsbawm, "Falklands Fallout", p. 60. This strategy had a long history in British socialism. For this history, consult P. Ward, Red Flag and Union Jack: Englishness, Patriotism and the British Left, I88I-1924 (Woodbridge, I998). For a shorter account that also considers the postWorld-War-II period, see M. Taylor, "Patriotism, History and the Left in Twentieth-Century Britain”, The Historical Journal, 33 (1990), pp. 971-987. 
patriotism was any less susceptible "to ruling-class jingoism, to antiforeign nationalism and $[. .$.$] to racism" 85$ than socialists had traditionally supposed. But when socialism and patriotism were harnessed together, he argued, they multiplied not only "the force of the working-class but [also] its capacity to place itself at the head of a broad coalition for social change, and they even give it possibility of wresting hegemony from the class enemy". ${ }^{86}$ Patriotism, in this view, was a contested discourse open to socialist inflection, while socialism's ability to define the national interest was supposed paramount to the Left's ability to realize political hegemony. ${ }^{87}$ For Hobsbawm, in this mind, Marxism could not be antinationalist but must paint itself in the national colors. ${ }^{88}$

Thus, in the context of socialist defeat, Hobsbawm dispensed with the notion that socialism was likely to end up subordinate to nationalism in any marriage of the two. Indeed, from the perspective of his critique of The Break-Up of Britain, Hobsbawm's "socialist patriotism" was likely to torpedo the central animating purpose of Marxist politics: that nations are divided by class and that ideologies of national patriotism favor class collaboration rather than class conflict. ${ }^{89}$ In addition, his "socialist patriotism" obliterated if not the internationalism then certainly the cosmopolitanism which he had previously argued was the ultimate horizon of the Marxian worldview. In his earlier mind, it was dangerous for Marxists to be patriots; in his latter mind, it was "dangerous to leave patriotism exclusively to the right". ${ }^{\circ}$ In the earlier, Marxists should not paint nationalism red, in the latter he advised socialists to get out their paint brushes.

However, there was no good reason for supposing that his "socialist patriotism" was not widening "the already evident gap between Marxism as the analysis of what is, or is coming into being, and Marxism as the formulation of what we want to happen", ${ }^{\mathrm{I}}$ as he had argued that Nairn's

85. Hobsbawm, "Falklands Fallout", p. 60.

86. Ibid. For his historical demonstration of this point, see Hobsbawm, "Fifty Years of Peoples' Front”, pp. 103-1 17. For a dissenting view, consider Anderson, Spectrum, p. 290.

87. This idea was a feature of Stuart Hall's analysis of national identity in the r 980 os. See S. Hall, "The Battle for Socialist Ideas in the I980s", in idem, The Hard Road to Renewal: Thatcherism and the Crisis of the Left (London, 1988), pp. 191-192.

88. In this mind Hobsbawm would find himself in company with a lot of non-Marxist socialists - including (according to Paul Ward) Hugh Dalton, Ramsay MacDonald, and Richard Crossman. See P. Ward, "Preparing for the People's War: Labour and Patriotism in the I930s", Labour History Review, 67 (2002), p. 172.

89. For the argument that nationalism obscures class conflict, see J. Schwarzmantel, "Nation versus Class: Nationalism and Socialism in Theory and Practice", in J. Coakley (ed.), The Social Origins of National Movements: The Contemporary West European Experience (London, 1992), pp. $48-49$.

90. Hobsbawm, "Falklands Fallout", p. 60.

91. Idem, "Reflections on 'The Break-Up of Britain'”, p. I3. 
separatist nationalism did. Just as dangerously, his (British) patriotism, in concert with his dismissal of Scottish separatist nationalism, left him open to the charge that his internationalism was a disguise for "big-state" nationalism..$^{92}$ The charge is partly justified - although in this register Hobsbawm was an instrumental nationalist rather than a nationalist, i.e. he only supported the maintenance of Britain's "national" integrity because he believed the alternative was actively harmful to the future of British socialism - and his conflicted understanding of Marxism's relation to nationalism invited it.

Hence, when it came to the nexus between socialism and nationalism Hobsbawm appeared caught in two minds. In one moment he suggested that Marxists could not be nationalists and endorsed a "Luxemburgist" interpretation of the national question. Marxists, he argued, could not "avoid swimming dead against the stream of local patriotism", a position reinforced by the historic fact that socialist movements that had sought to mobilize nationalism for their own purpose "tended to become national not only in form but in substance i.e. nationalist". ${ }^{93}$ This was a past he lamented and warned Marxists against repeating in the context of the rise of separatist nationalism. In another moment, however, he suggested that socialists should attempt to define the nation in socialist ways and that the success of socialism was dependent on a (socialist) rearticulation of nationalism. In this mind he argued that socialists could not legitimate their ideological discourse unless it was reconciled to what Gramsci called the "national-popular". ${ }^{44}$ What might explain the disjunction between these two views?

One obvious candidate is context. His socialist-patriotism was framed in the depths of Left defeat and New Right triumph, when it appeared that national identity had finally trumped class-consciousness; his socialist internationalism was framed in a period when hopes for socialist advance, no matter how attenuated, could still be entertained, no matter with what degree of hesitation. But there is another related explanation linked to Hobsbawm's biography. The internal conflict within Hobsbawm's understanding of the nexus between socialism and nationalism could be a consequence of the dissonance between his formation as a communist in Berlin during the early I930s and his later experience of the Popular Front and the "People's War" in Britain. Hobsbawm pointed to this discord in Interesting Times:

92. This, of course, was Tom Nairn's charge. See Nairn, Faces of Nationalism, pp. 42-44.

93. Hobsbawm, "Reflections on 'The Break-Up of Britain”, p. I 3.

94. Gramsci's concept of the "national-popular" was important to Hall's attempt to build a nationalist socialism in Britain in the I980s. On Hall's vision of a socialism reconciled to national belonging, see S. Hall, "The Toad in the Garden: Thatcherism among the Theorists", in C. Nelson and L. Grossberg (eds), Marxism and the Interpretation of Culture (Urbana, IL [etc.], I988), pp. $35-57$. 
Politically, having actually joined a Communist Party in 1936, I belong to the era of anti-fascist unity and the Popular Front. It continues to determine my strategic thinking in politics to this day. But emotionally, as one converted as a teenager in the Berlin of 1932, I belonged to the generation tied by an almost unbreakable umbilical cord to hope of the world revolution, and of its original home, the October Revolution, however sceptical or critical of the USSR.95

The discord, as Perry Anderson has suggested, had an important impact on his thought. ${ }^{96}$ No more so, it might be argued, than on his thinking about the nexus between socialism and nationalism.

\section{DO WORKERS HAVE A COUNTRY? CLASS- \\ CONSCIOUSNESS AND NATIONAL IDENTITY}

Does the proletariat have a homeland? When decrying the claims of all nationalities, whether dominant, residual or emergent, Marx and Engels answered this question with characteristic force: "The nationality of the worker is neither French, nor English, nor German, it is labour, free slavery, self-buckersting. His government is neither French, nor English, nor German, it is capital."97 Modern industry, according to Marx and Engels, "[had] stripped [the worker] of every trace of national character".$^{98}$ In a world where capital allowed "no other nexus between man and man than naked self-interest", where "egotistical calculation" had removed the veil from the "heavenly ecstasies of religious fervour", 99 and where exploitation had been rendered cosmopolitan, the proletariat, they maintained, could have no interest in national particularisms. The proletariat was "an international historical subject" with "an international historical aim": the establishment of planetary socialism. ${ }^{100}$ In short, the workers did not have a country. ${ }^{\text {IOI }}$

95. Hobsbawm, Interesting Times, p. 2 I 8.

96. Anderson, Spectrum, p. 285.

97. K. Marx, "Draft of an Article on Friedrich List's Book, Das Nationale System Der Politischen Oekonomie (1845)", in Marx and Engels, Collected Works, IV (New York, 1975), p. 280. Italics appear in the original.

98. K. Marx and F. Engels, "Manifesto of the Communist Party", in Marx and Engels, Collected Works, VI (New York, 1975-), p. 494. For an explication of Marx's argument that the bourgeoisie universalized capitalist relations of production, see S. Avineri, The Political and Social Thought of Karl Marx (New York, 1969), pp. 162-174.

99. Marx and Engels, "Manifesto of the Communist Party", p. 487.

Iо०. Marx's and Engels's understanding of the "world-historical" nature of the proletariat and its aims is represented here in M. Löwy, "Fatherland or Mother Earth? Nationalism and Internationalism from a Socialist Perspective", in R. Miliband, L. Panitch, and J. Saville (eds), Socialist Register 1989: Revolution Today. Realities and Aspirations (London, I989), p. 2 I 4. IOI. Marx and Engels, "Manifesto of the Communist Party", p. 502. Elsewhere in the Communist Manifesto Marx and Engels argued that the proletariat "must rise to be the leading class of the nation". An analysis of Marx and Engels's encounter with nationhood and 
By the beginning of the I980s, Hobsbawm's assessment of this thesis was blunt: not only was "it wrong to assume that workers have no country", but class-consciousness "neither excludes nor, usually, dominates national sentiments". ${ }^{102}$ In brief, for him, the assessment of Marx at his most cosmopolitan, and his followers at their most anational, had been seriously flawed: "working-class consciousness", he believed, "is probably politically secondary to other kinds of consciousness", ${ }^{103}$ particularly national consciousness. However, the claim that "the workers have a country" was no more satisfactory, he argued, than its opposite.

A more nuanced interpretation of the relationship between proletariat and nationhood, Hobsbawm contended, was required to transcend the unhelpful dichotomy that maintained the working class was either internationalist or nationalist. Satisfied with proving the existence of working-class nationalism, or with explicating the determinative value of nation over class, and from there the invalidity of a Marxist conception of the national question, most students of nationalism have simply dismissed the Communist Manifesto's thesis as wildly erroneous. Hobsbawm partly agreed. But if he could consent that workers do indeed (at certain historical moments) have a country, this did not imply for him the need to overthrow a Marxist analysis of the national question.

Constructed during Thatcherism's ascent, Hobsbawm's assessment of the relationship between class and nation grew out of an awareness that proletarian identity was complex. If it was clear that the workers did have a country, it did not necessarily follow, he argued, "that they only have one, and we know what it is". ${ }^{104}$ It was not just that a "national" working class has never anywhere constituted an ethnically homogenous body. ${ }^{\text {IOS }}$ It was not just that bifurcations other than nationality - like those instituted by religion - were most likely to fracture any "national" working class. ${ }^{\text {Io } 6}$ And it was not just that most "national" working classes were composed of

nationalism can be found in E. Benner, Really Existing Nationalism: A Post-Communist View from Marx and Engels (Oxford, I995).

I02. E. Hobsbawm, "What is the Workers' Country?", pp. 58 and 49. This did not lead to the conclusion that workers were necessarily and always nationalist. A similar distinction between "national identity" and "nationalism" can be found in Löwy, "Fatherland or Mother Earth?", pp. 2I3-2I4.

I03. Hobsbawm, "What is the Workers' Country?", p. 60. For a similar argument from within the Marxist tradition, see G. Kitching, "Nationalism: The Instrumentalist Passion", Capital and Class, 29 (1984), p. I I4. See also E. Gellner, Encounters with Nationalism (Oxford, 1994), p. 2. I04. Hobsbawm, "What is the Workers' Country?", p. 49.

105. See Hobsbawm, The Age of Empire, pp. I 1 8-i 24 for the reasons why. In addition, consult Hobsbawm, "What is the Workers' Country?", p. 49, and idem, "Working Class Internationalism", in F. van Holthoon and M. van der Linden (eds), Internationalism and the Labour Movement (New York, I988), pp. I2-I3.

Io6. Hobsbawm, "What is the Workers' Country?", p. 49. On religion as a solvent of workingclass unity, see D. Geary, "Working-Class Identities in Europe, I850s-1930s", Australian Journal of Politics and History, 45 (1995), pp. 20-34. 
individual workers with multiple sets of identification. ${ }^{107}$ It was that in most cases, he argued, a working class's national identity did not necessarily conflict with its identity as a class. Indeed, no matter how virulent or chauvinistic any particular form of proletarian nationalism, it did not prevent the expression of what Hobsbawm, following Lenin, called a "trade union consciousness" - that is, "the recognition that workers as such need to organize effectively against employers in order to defend and improve their conditions as hired hands". ${ }^{108}$

It was only when class solidarity conflicted with a worker's national identity, or where a national movement existed prior to working-class formation, that national consciousness proved a solvent of proletarian unity. National identity, Hobsbawm argued, did not always and everywhere trump class, at least not in the objective sense of "trade union consciousness", and national identity was not automatically irreconcilable with class politics. What nationalism did tend to obliterate was something he called "socialist consciousness" - that is, an awareness of the international character of proletarian interest and intent. ${ }^{109}$ It was this form of social and cultural expression, Hobsbawm concluded, that had been decisively routed by nationalism.

This argument would provide cold comfort for class warriors who, following The Communist Manifesto, sought to "point out and bring to the front the common interests of the entire proletariat, independently of all nationality". ${ }^{\text {Io }}$ More hopefully, Hobsbawm's argument did point to the fact that national identity did not always and everywhere trump class. How else could one explain the genuinely "internationalist" character of "trade union consciousness" in places such as Budapest and Rhondda? III How else could one explain those situations, like that prevalent in pre-I9I 4 Vienna, where communal and national differences did not prevent a social democratic party from organizing workers on a class basis? Hence, it was

ı07. Hobsbawm, "Working Class Internationalism", p. I3, and idem, "What is the Workers' Country?”, p. 49.

108. Hobsbawm, "What is the Workers' Country,?", pp. 57-58. See also idem, The Age of Empire, p. I 21, and "Working Class Internationalism", pp. 9-10. For Lenin's conception of class, see A. Shandro, "Consciousness from Without': Marxism, Lenin and the Proletariat", Science and Society, 59 (1995), pp. 268-297.

I09. See Hobsbawm, The Age of Empire, p. I 21. Once again Hobsbawm's distinction between "trade union consciousness" (an objective sense of class or class-in-itself) and "socialist consciousness" (the marriage of an objective and a subjective sense of class or class-in-and-foritself) owed much to the Leninist tradition. For an overview and critique of this distinction in Marxism, see A. Przeworkski, "Proletariat into a Class: The Process of Class Formation from Karl Kautsky's The Class Struggle to Recent Controversies", Politics and Society, 7 (1977), pp. 343-40I.

I I0. Marx and Engels, "Manifesto of the Communist Party", p. 497.

I I. See Hobsbawm, "Working Class Internationalism", pp. 8-9, and The Age of Empire, p. I 20. 
not only specific instances where class interest had proved resistant to fracture along communal or national lines within "national" working classes that advised caution when considering the relationship between class and nation. There were also concrete instances of genuine workingclass internationalism where class interest did transcend national borders and communal divisions, where, as Hobsbawm argued, workers experienced internationalism as a genuine reality of their class situation. ${ }^{\text {II }}$ Nonetheless, class identity, in the sense of an objective sense of classness, did not prevent other forms of identity emerging within any particular working class, especially not national identity; and objective classconsciousness, far from guaranteeing the rise of a socialist consciousness, most often succumbed to other forms of identity when they came into conflict.

Hobsbawm argued that Marxist theory could account for this. Although class, in its objective sense, was a feature of both pre-capitalist and capitalist societies, the span and depth of class-consciousness, he argued, was determined by the experienced scale of economic reality in which subaltern classes lived, labored, and struggled. Pre-capitalist societies, rooted in parcellized, essentially local, economic units were characterized by low "classness" among subaltern strata; class and class conflict still existed but class-consciousness was typically fragmented and bounded by the geographic scale of economic production. ${ }^{113}$ Constituted as "territorial states", capitalist societies, however, were typified by an expanded "classness", that is, by what Hobsbawm called "national" class-consciousness. In the modern economy, based on the interdependence of national economic units, the "real and effective classes are national". ${ }^{14}$ "The working class's lived experience was the "national economy"; the "scale of class consciousness" was " "national' not global". ${ }^{\text {Is }}$ A consciousness of the working class's global interests in such a situation was an unrealized potential whose transposition to an existential reality awaited the genuine transnationalization of the world economy. Hence, if nation trumped class then the territorial logic of economic development, Hobsbawm argued, could explain why this was so.

Thus, for Hobsbawm, there were material factors, immersed within the territorial logic of capitalist development, which explained the necessarily national form of proletarian consciousness. Not only had "the national economy of the state" been the most important defining force in workers'

I 12. Idem, The Age of Empire, p. I20.

i 13. Idem, "Class Consciousness in History", in I. Mészáros (ed.), Class Consciousness and History (London, I972), p. Iо. See also idem, "The Development of the World Economy", Cambridge Journal of Economics, 3 (1979), pp. 313-3i4.

I I 4. Hobsbawm, "Class Consciousness in History", p. i I.

I I s. Ibid. 
lives; ${ }^{116}$ not only had the working class been nationalized from above through the state's extension of citizenship and democracy, and through the homogenizing tendencies of national culture and education; ${ }^{\text {II }}{ }^{\text {but also }}$ working-class organization itself - "national" trade-union movements, "national" labour parties - had effectively nationalized workers from below. Indeed it was precisely mass working-class movements in the late nineteenth and early twentieth centuries, he argued, which had exerted pressure on states to deliver democracy and nascent forms of welfare, effectively transforming proletarians into citizens. Developments in the first three quarters of the twentieth century intensified this process, a process struggled for and endorsed by "international" class parties. ${ }^{118}$ The welfare state, national labour laws, positive trade union legislation, and the nationalization of industries - all the historic achievements of Western labour movements had deepened the "nationalization of the masses". ${ }^{119}$ The logic of Hobsbawm's argument, then, was clear: national identity had been as necessary and historically determined a form of consciousness among the working class as class identity, nationalism no less an authentic response to a capitalist world-system rooted in national states than socialism. ${ }^{120}$

Hobsbawm's analysis of the nexus between national identity and classconsciousness, then, destabilized (perhaps better, obliterated) many of the long-held axioms of Marxist theory. He argued that class-consciousness was most often trumped by national identity when the two came into conflict, although he noted that the two could coexist easily enough when not in competition. Nonetheless this argument contradicted the view of those Marxists, including Marx and Engels, who claimed that classconsciousness would ultimately extinguish national identity. In addition, if a trade-union consciousness had often coexisted with national identity, sometimes even nationalism, this was certainly not true of socialist

I 16. Idem, "What is the Workers' Country?", p. 49, and The Age of Empire, p. I 28.

i 17. Hobsbawm, The Age of Empire, pp. I49-15 I. For a similar reading, see C. Calhoun, "Nationalism and Ethnicity", Annual Review of Sociology, I9 (1993), p. 217.

I 18. Hobsbawm, The Age of Empire, pp. I26-i 29. For a similar argument, see Th. Van Tijn, "Nationalism and the Socialist Workers' Movement", in Internationalism and the Labour Movement, pp. 6i I-623.

I19. The phrase is taken from G.L. Mosse, The Nationalization of the Masses: Political Symbolism and Mass Movements in Germany from the Napoleonic Wars through the Third Reich (New York, 1975). For Hobsbawm's elaboration of this process, see "Working Class Internationalism", p. I4. For an account of the "national integration" of European working classes in the nineteenth century, see M. van der Linden, "The National Integration of European Working Classes (I87I-1914): Explaining the Causal Connection", International Review of Social History, 33 (1988), pp. 288-3 I I.

I 20. Hobsbawm, "Working Class Internationalism", p. 7. On this point, also see J. Ehrenreich, "Socialism, Nationalism and Capitalist Development", Review of Radical Political Economics, is (1983), p. 8. 
consciousness, which, whether in I9I4 or 1933, had been consistently undermined by the proletariat's sense of national belonging. Socialist internationalism, Hobsbawm lamented, was more likely to be found among a small group of activist-intellectuals than among the mass of workers. ${ }^{\text {I2I }}$

There were good historical materialist reasons, Hobsbawm suggested, for why nation had most often overtopped class, reasons moored in the material exigencies of the working class's lived experience. A consciousness of themselves as a global class had been unavailable to the world's workers for much of capitalism's history. Why, then, had the proletariat most often chosen nation over class? Because, Hobsbawm argued, they inhabited national economies and national states. The workers did have a country, and they had a country because it was crucial to the maintenance of their material existence. Given the continuing uneven development of capitalism - the fact that workers' conditions were not the same everywhere - this, he went on to suggest, was unlikely to change. Thus, Hobsbawm's analysis of the nexus between class and nation coalesced into a version of what Alvin W. Gouldner has called "nightmare Marxism" I22 that is, a type of Marxism that could account for Marxism's defeat and explain why the establishment of a worldwide socialist community was impossible. In this view, an eternal national class-consciousness rather than the fulfillment of the Communist Manifesto's call to global class war represented a more probable estimation of the working class's future.

Hobsbawm's "nightmare Marxism" was not just informed by his reading of social reality or objective developments, but also by his "social being" - his detachment from political activism reflected in a "mode of writing" attuned to structure and pattern rather than human agency. Thus, his analysis of the nexus between class-consciousness and national identity often assumed the veneer of fatality, as though the hegemony of nation over class was a historically determined fact rather than a reflection of political contingency. Workers have been mobilized across ethnic and national lines in the past partly because of the political endeavors of class warriors and their organizations. Where class has trumped nation - and Hobsbawm often enough pointed to such examples - this agency has been paramount. In other words, Hobsbawm's analysis of the relationship between national identity and class-consciousness obfuscated or underplayed the contingent effect of political agency in the determination of proletarian identity. Working-class consciousness is not necessarily secondary to national consciousness as Hobsbawm assumed. Rather the nexus between nation and class is in large measure a product of the

I21. Hobsbawm, The Age of Empire, p. I29.

I22. A.W. Gouldner, The Two Marxisms: Contradictions and Anomalies in the Development of Theory (New York, I980), pp. 380-389. 
presence or absence of the subjective mobilization of class forces. Formed in the turmoil of street-battles between communists and fascists, a Marxist historian might have been expected to recognize as much.

\section{NATIONHOOD, NATIONALISM AND THE WORLD ECONOMY: THE END OF NATIONS OR NATIONS AS THE END OF HISTORY?}

Capital's accumulation imperative, and its corresponding need to universalize market relations, would necessarily undermine the national basis of industry according to the Communist Manifesto. ${ }^{23}$ In a world dominated by the capitalist mode of production, national industries, perhaps even national states, would be swept away by a world market whose limit was profit not nationality. National industry, scientific socialism's founders claimed, would be destroyed "by industries that no longer work up indigenous raw material, but raw material drawn from the remotest zones; industries whose products are consumed, not only at home, but in every corner of the globe". ${ }^{124}$ Thus capitalism, in the Communist Manifesto's version of its advance, impelled cosmopolitanism. ${ }^{125}$ What did Hobsbawm make of this vision of universal development and national collapse? Through an analysis of his four-volume history of the modern world and his recent writing on the national question, this final section of the article will explore Hobsbawm's understanding of the relationship between "Gemeinschaft and globalization" ${ }^{226}$ in the last third of the twentieth century.

Ritually lionized, although less often analysed, ${ }^{127}$ Hobsbawm's history of the modern world can be read as a narrative of how capitalist globalization first created and then enervated the nation state, "the central

I 23. For the geographical implications of the Manifesto's analysis of capitalism, see D. Harvey, Spaces of Hope (Berkeley, CA, 2000), pp. $2 \mathrm{I}-40$.

I24. Marx and Engels, "Manifesto of the Communist Party", p. 488.

I25. For an explication of this characteristic Marxist argument, see I. Wallerstein, "The Ideological Tensions of Capitalism: Universalism versus Racism and Sexism”, in E. Balibar and Wallerstein, Race, Nation, Class: Ambiguous Identities (London, 1991), pp. 29-36. This constitutes only one of Marx's understandings of the history of capitalism. In another version, also outlined in The Communist Manifesto, capitalist advance implied the establishment of national states. See G. Balakrishnan, “The National Imagination”, in Balakrishnan, Mapping the Nation, p. 198.

I 26. T.J. Clark, "In a Pomegranate Chandelier”, London Review of Books, 28:1 8 (2 I September 2006), p. 6.

I 27. An exception is Anderson, Spectrum, pp. 293-332. Both Edward Said and Göran Therborn have offered insightful commentaries on the last volume, Age of Extremes. See Said, "Contra Mundane: On Eric Hobsbawm", pp. 474-483 and G. Therbron, "The Autobiography of the Twentieth Century”, New Left Review, I/2 I 4 (1995), pp. 8 I -90. For a more critical assessment of Hobsbawm's volume, see T. Nairn, "Breakwaters of 2000: From Ethnic to Civic Nationalism", New Left Review, I/2 I4 (1995), pp. 91-103. 
institution of politics since the Age of Revolution". ${ }^{128}$ Indeed, structured by a conception of the shifting dialectic between liberalism and nationalism, his tetralogy of the contemporary world explains the rise and fall of the nation state both as a means of organizing the world economy and as a form of social and political organization.

The first volume, The Age of Revolution, I789-I848, maps the genesis of the "characteristic modern state" - "a coherent and unbroken area with sharply defined frontiers, governed by a single sovereign authority and according to a fundamental system of administration and law". ${ }^{29}$ The second volume, The Age of Capital, I848-1875, shows how this political superstructure was effectively universalized throughout Europe and explores the complementary imbrications of nation-building and capitalist development. ${ }^{130}$ The Age of Empire, 1875-1914 charts the process by which the capitalist world-economy was increasingly constituted as a set of rival national economies competing for profit and influence, tracks "the retreat of the free competitive market", ${ }^{13 \mathrm{I}}$ and explains how the growth of protectionism, capitalist concentration and centralization, and imperialism prepared the way for the global conflagration of I9I4-I9I8 and the apotheosis of economic autarky during the interwar period. ${ }^{132}$

These results - war, the Great Slump, and fascism - would be explored in the first half of the final volume of the tetralogy, Age of Extremes: The Short Twentieth Century, I9I4-1990. In its second half, the book tracked the post-World-War-II demise of both national economics and the national state. "By the end of the [twentieth] century", Hobsbawm concluded,

[...] the nation-state was on the defensive against a world economy it could not control; against the institutions it had constructed to remedy its own international weakness, such as the European Union; against its apparent financial incapacity to maintain the services to its citizens so confidently undertaken a few decades before; against its real incapacity to maintain what, by its own citizens, was a major function: the maintenance of law and order. ${ }^{133}$

In short, the "range, powers and functions" of the nation state, which had I 28. Hobsbawm, Age of Extremes, p. 575. Benedict Anderson has a very different conception of the origins of nationhood and nationalism. See the chapter "Creole Pioneers" in his Imagined Communities, pp. 47-66.

I 29. Hobsbawm, The Age of Revolution, p. I I 3. For a more recent account of the "birth of the nation state", which links it to developments in the capitalist mode of production, see E.M. Wood, The Origins of Capitalism: A Longer View (London, 2002), pp. I66-i 8 I.

I30. Hobsbawm, The Age of Capital, pp. 82-86 and I I.

I 3 I. Idem, The Age of Empire, p. 35. This period of "national economics" and its results was also tracked in idem, Nations and Nationalism since 1780 , pp. I 3 I-I 32.

132. Idem, The Age of Empire, pp. 40-43, 52-56,64-73 and I 42 in particular.

133. Idem, Age of Extremes, p. 576. For a rejection of Hobsbawm's argument, see M. Mann,

"Has Globalization Ended the Rise and Rise of the Nation State?", Review of International Political Economy, 4 (1997), pp. 472-496. 
been extending "almost continuously" from the eighteenth century onwards, had been precipitously diminished by the close of the Age of Extremes. ${ }^{134}$ Thus, despite the formal persistence of territorially embedded states (the "United Nations"), at the dawn of a new millennium, Hobsbawm claimed, modern political economy had obliterated the idea of the sovereign, independent nation state to which the French Revolution had given birth. Thus, a history of the contemporary world which opened with the genesis of nationhood in the era of the dual revolutions, closed at the "end of history" 35 with the nation state's denouement.

The powers of the nation state, according to Hobsbawm, had been attenuated, above all, by an increasingly transnational mode of capitalist production. National economics, he claimed, had been overridden by "the new international division of labour", by the growing reach and power of transnational enterprises and by "the rise of offshore finance". ${ }^{136}$ In short, a world economy now constituted by "free economic flows across borders" 37 had "undermined a major, and since 1945 , universal institution: the territorial nation state, since such a state could no longer control more than a diminishing part of its affairs". ${ }^{13^{8}}$ Intimations of this view had been present in his earlier writings. In 1979, for example, he maintained that "the emergence or re-emergence of forms of economic organization which not only cut across or transcend boundaries of national economies but compete with them and may be beyond their control, is hardly to be denied". ${ }^{139}$ His view that an increasingly global market augured the doom of the national state was repeated and extended in Nations and Nationalism since 1780 and in Age of Extremes. ${ }^{10}{ }^{\circ}$ By the last century's fin de siècle, according to both books, the co-dependent relationship between nationhood and capitalist development - characteristic of that period of modern history between the French Revolution and the era of decolonization - had been definitively sundered.

Nation states, of course, cannot be reduced to their economic role, no matter how important "national economics" to effective independence. ${ }^{14 \mathrm{I}}$ In other words, the historic nation state has not only functioned as a

I34. Hobsbawm, Age of Extremes, p. 576.

I 35. Interestingly, despite believing that socialism is dead, Hobsbawm does not subscribe to Fukuyama's "end of history" thesis. For an example of his rejection of Fukuyama's argument, see E. Hobsbawm, "1989: To the Victor the Spoils", The Independent, 2 October 1990.

136. Idem, Age of Extremes, p. 277.

I37. Ibid., p. 4I4.

I38. Ibid., p. 424 .

I39. Hobsbawm, "The Development of the World Economy", p. 3 i 5.

I40. See idem, Nation and Nationalism since 1780 , pp. I8I-I82 and Hobsbawm, Age of Extremes, p. 408.

I4I. The idea of "national economics" is associated with Friedrich List. For his ideas, particularly in relation to Marxism, see R. Szporluck, Communism and Nationalism: Karl Marx versus Friedrich List (New York [etc.], 1988), pp. I I -169. 
"national economy" - it has also functioned as a system of welfare, ${ }^{142}$ as a means of propagating war and securing civil order, and as a primary locus of meaning and identity. According to Hobsbawm, all these functions of the nation state - welfare, warfare, order and meaning - were in a state of rapid disintegration by the end of the twentieth century. National armies, once a force of national integration and central to both warfare and social order, were being increasingly privatized and professionalized, he claimed, rendering them more akin to the mercenary armies of the eighteenth century rather than the national conscription armies of the early twentieth. ${ }^{143}$ Privatized armies were a measure of the international order: "In military terms", Hobsbawm trenchantly surmised, "the idea of a 'world of nations', [was] a nonsense". ${ }^{\text {I44 }}$

If nation states no longer fitted the role of warfare state in terms of international relations by the end of the twentieth century, they were no more likely to be able to guarantee the safety of their own citizens. ${ }^{\text {I4 }}{ }^{2}$ Indeed, in some cases, Hobsbawm noted, the national state was no longer the sole locus of legitimate violence, public law enforcement having given way to privatized policing. ${ }^{146}$ Economic developments had also imperiled the national state's welfare functions. "Homes fit for Heroes", New Deals, and Beveridge Reports were anachronisms in an age where economic doxa maintained that all aspects of human life - including health, education and welfare - could be reduced to profit and loss. In such circumstances, the ties which bound citizens to their "nations" were being increasingly loosened. Personal meaning and forces of integration would now be found outside the "traditional" nation-state - as Hobsbawm believed they were in the exponential growth of "identity politics", whether of the religious fundamentalist or the ethnic nationalist type. ${ }^{\mathrm{I}} 4 \mathrm{U}$ Unburdened of its economic, political and meaning functions, the nation state, in this view,

I42. On this point, see G. Eley and R. Grigor Suny, "Introduction: From the Moment of Social History to the Work of Cultural Representation", in idem (eds), Becoming National (New York, I996), p. 26.

I43. Hobsbawm, The New Century, pp. I2-I3. On the relationship between conscription and nationalism, see V. Kiernan, "Conscription and Society in Europe before the War of I9I4I9r 8”, in H. Kaye (ed.), History, Classes and Nation-States: Selected Writings of V.G. Kiernan (Cambridge, 1988), pp. I66-185. On the "privatization" of military services, see D. Harvey, Spaces of Global Capitalism: Towards a Theory of Uneven Geographical Development (London [etc.], 2006), p. 44.

I44. Hobsbawm, Nations and Nationalism since 1780 , p. I85 and idem, "The Nation and Globalization", Constellations, 5 (1998), p. 7.

I45. Hobsbawm, Age of Extremes, p. 560. For a different reading of the global economy, see W.I. Robinson, A Theory of Global Capitalism: Production, Class and the State in a Transnational World (Baltimore, MD, 2004).

I46. Hobsbawm, The New Century, p. 34 .

I47. See Hobsbawm, Nations and Nationalism since I780, pp. I70 and I79, and idem, "Ethnicity and Nationalism Today", Anthropology Today, 8 (1992), p. 4. 
survived as a mystical shell - a conclusion unhelpful to those still fighting to establish their own nation states free of imperial domination. ${ }^{148}$

Hobsbawm's vision of the nation state's demise, however, was tempered by a significant caveat. As early as the late I970s, Hobsbawm's argument was complicated by his seemingly antagonistic opinion that "national economics" had not been extinguished by the global market but operated as its "rival". ${ }^{149}$ In this mind, he suggested that a transnational economy and national economies co-existed and that "one would not replace the other". ${ }^{\text {I50 }}$ Indeed, he claimed that "both [the transnational economy and national economies] are or have been growing in strength". ISI The course of the next two decades did not alter this opinion. In Nation and Nationalism since $I 780$ he argued that national economies, "however undermined by the transnational economy, coexist and intertwine with it". ${ }^{152}$ In fact, beyond this cautious amendment to his "end of the nation state" thesis, Hobsbawm suggested that capitalist globalization did not imply that the "economic function of states have been diminished or are likely to fade away;" "53 while elsewhere he argued that the transnational economy was necessarily refracted through a national "political grid" and that, in certain cases, the national state's welfare functions would actually increase. ${ }^{154}$ In this respect, at least, the nation state was now "indispensable". ${ }^{\text {Iss }}$ So much then for its demise.

Hence, when it came to considering the relationship between capitalist globalization and the nation state, Hobsbawm waxed ambiguous. ${ }^{156}$ On the one hand, in the footprints of the Communist Manifesto, he argued that

148. See N. Lazarus, Nationalism and Cultural Practice in the Postcolonial World (Cambridge, 1999), pp. 70-76, for a critique of Hobsbawm's "end of the nation-state" thesis. Arguably, Hobsbawm has not been sufficiently attentive to the progressive role that nation form has played in the struggle against colonialism. As Gopal Balakrishnan has suggested, "The nation became a central figure in the radical political imagination of the twentieth century." See Balakrishnan, "The National Imagination", p. 2 I 2.

149. Hobsbawm, "The Development of the World Economy", p. 3i6. A similar argument is made in E.M. Wood, "Global Capital and National States", in M. Rupert and H. Smith (eds), Historical Materialism and Globalization (London, 2002), pp. 17-34.

i so. Hobsbawm, "The Development of the World Economy", p. 3 I6.

Is I. Ibid.

I 5 2. Hobsbawm, Nations and Nationalism since I780, p. I 82.

I 53. Ibid. For a similar argument, see idem, "The Nation and Globalization", p. 2. For a trenchant statement along these lines, see L. Weiss, "Globalization and the Myth of the Powerless State”, New Left Review, I/225 (1997), pp. 3-37.

I 54. Hobsbawm, "Guessing about Global Change", International Working Class and Labor History, 47 (1995), p. 43.

I55. Idem, The New Century, p. 84 .

I 56. For scholarly overviews of the debate on the relationship between globalization and nationhood, see K. Neilsen, "Are Nation-States Obsolete? The Challenge of Globalization”, in M. Seymour (ed.), The Fate of the Nation State (Montreal [etc.], 2004), pp. I 53-172, and C. Bartolovich, "Global Capital and Transnationalism", in H. Schwarz and S. Ray (eds), A Companion to Postcolonial Studies (Malden, 2000), pp. I27-I 34 . 
the universalization of commodity production impelled the destruction of "national economics", and even of national states, whether in terms of their social, political or military function. On the other hand he tempered, if not contradicted, this view by asserting that "national economics" and the "welfare state", at least in developed countries, were becoming stronger and more deeply embedded in nation-states as the capitalist world economy became more and more transnational.

At first sight, contradiction would appear the most obvious conclusion to draw. Antinomy, however, is not always the mark of a fatal flaw in argument; it may express conflicting tendencies in social reality. This is the most fruitful way to approach Hobsbawm's understanding of the nexus between "Gemeinshaft and globalization". Thus his ambivalent assessment of the nation state's future was a reflection of a contemporary reality constituted by both the IMF and uneven capitalist development, by global cultural homogeneity and wide divergences in the material conditions of labor. ${ }^{157}$ In a world where the life-chances of workers in Beijing and Brisbane were still poles apart, it was hard to argue that the "national economy" and the "national state" constituted residues of "prehistory". ${ }^{\text {is }} 8$ But it was equally hard to deny that "national economics" and the "national state" retained their historic powers in a world dominated by the hegemonic order of capital and where the ideology of neo-liberalism ruled unchallenged. In such circumstances a vacillating ensemble of cosmopolitan and particularist reflexes perhaps constitutes an accurate reflection of objective developments. ${ }^{\text {I59 }}$

Not just a fine-spun portrayal of social reality, the ambiguity in Hobsbawm's assessment of the relationship between capitalist globalization and the nation state also spoke to and reflected the increasing sophistication and complexity of contemporary historical materialism - its aversion to reductionism, to simplistic explanations deriving from some final instance of determination, and of its increasing ability to incorporate modes of being and identity other than class into its theoretical orbit. It might be argued that these qualities have always characterized Marxism; but Hobsbawm's complex view of the nexus between the nation state and capitalist globalization was a sure sign of historical materialism's ability to comprehend our world's "erratic unity of opposites". ${ }^{60}$ However, it also

I57. On global cultural homogeneity, see Hobsbawm, "The Nation and Globalization", pp. 5-6.

I 58. On this point, consult Harvey, Spaces of Hope, p. 40.

I 59. For a recent interpretation of contemporary reality that accords with Hobsbawm's, see D.

Laibman, "Theory and Necessity: The Stadial Foundations of the Present", Science and Society, 69 (2005), pp. 305-3I 2.

I60. I borrow this phrase from J. Petras, "Marx and Engels and the National Question", p. 797. For Hobsbawm's own understanding of "dialectics" see Hobsbawm, "What Do Historians Owe Karl Marx?”, p. I53. 
reflected another contradictory reality: the more penetrating and complex Marxism became, the more vulnerable it was to nightmares. In other words, as historical materialism developed into an ever-more artful tool for understanding the world, it seemed less and less likely to provide an adequate guide for those who sought to change it. Always respectful of empirical controls, historical materialism increasingly faced a social reality that was imperiously set against it.

If Hobsbawm's analysis of the relationship between the nation state and capitalist globalization was characterized by complex ambiguity, part product of objective reality, part product of historical materialism's increasing sophistication, what of his assessment of the future of nationalism? According to Hobsbawm, nationalism, like the national state, was vulnerable to the enlightenment derived from the flight of Minerva's owl. In short, he believed nationalism was entering the dusk of its world-historical influence. Paradoxically, "the end of nationalism", he argued, was most clearly illuminated by the rise of ethnic nationalism and identity politics in the twentieth century's final decades. ${ }^{161}$ Hobsbawm maintained that despite, but also because of, the emergence of separatist nationalisms in traditional nation states and the crystallization of ethnic nationalisms in post-socialist societies, that nationalism no longer constituted a major historical force in the way that it had "in the era between the French Revolution and the end of imperialist colonialism after World War II". ${ }^{162}$

This argument - that "nationalism as a vector of historical change"163 was now in decline - constituted the most controversial claim of Hobsbawm's mature analysis of the national question - it was the central argument of Nations and Nationalism since 1780 - although it was prefigured in his earlier work. ${ }^{64}$ The claim was controversial for it seemed to run against the grain of the facts, especially following the nationalist explosions which attended state socialism's ruin in the last decades of the twentieth century. ${ }^{165}$

Hobsbawm did not suppose, however, that there would be less nationalism around. ${ }^{166}$ Rather he claimed the nationalism that had facilitated "the building of a number of 'nations' that combined nation-

i6r. Hobsbawm, Age of Extremes, p. 430.

162. Idem, Nation and Nationalism since 1780 , p. I69.

163. Ibid., p. I 50.

164. For an early indication of this argument, see, in particular, E. Hobsbawm, "Some Reflections on Nationalism", in T.J. Nossiter, A.H. Hanson, S. Rokkan (eds), Imagination and Precision in the Social Sciences: Essays in Memory of Peter Nettl (London, 1972), p. 406.

I65. For a critique of this claim from within the Marxist tradition see M. Löwy, "Why Nationalism?", in R. Miliband and L. Panitch (eds), Real Problems, False Solutions: Socialist Register (London, 1993), pp. I29-130.

166. Hobsbawm, Nation and Nationalism since I780, p. I8 I. 
state and national economy" 167 would be less in evidence, the sort of nationalism based on a "body of citizens in a territorial state", which "extended the scale of human society", and which had constituted a "global programme" between the late eighteenth-century and the midtwentieth century. ${ }^{168}$ This kind of nationalism, he argued, not nationalism tout court, constituted a historical vector in decline. The ethnic and separatist nationalisms that had achieved ascendancy in the last three decades of the twentieth century were radically different to this "universalist" nationalism. "Nationalist" nationalism, unlike "universalist" nationalism, sought to break up existing states, based its claim to nationhood on appeals to ethnicity and language, and repudiated the legacy of the eighteenth-century Enlightenment. ${ }^{169}$ Like identity politics, xenophobia, and racism, "nationalist" nationalism, Hobsbawm suggested, was not evidence of nationalism's revitalization but symbolic of the "distress and fury" and the "social disorientation" characteristic of the late twentieth century, a view wildly out of step with Benedict Anderson's claim "that nations inspire love, and often profoundly self-sacrificing love". ${ }^{170}$ In Hobsbawm's view, not only was "nationalist" nationalism more likely to constitute a "substitute for lost dreams" "171 rather than an expression of love, it was a pseudo world-historical force which claimed an illusionary vitality from a mistaken association with a "universalist" nationalism that had transformed the world between the French Revolution and the I970s. ${ }^{172}$

Thus, as far as "universalist" nationalism was concerned, Hobsbawm believed that the Owl had flown - we could now illuminate what it was because its historical strength was exhausted. In fact, his verdict on nationalism's future was not so clear-cut. This is not only because he maintained that we would not see less nationalism around - specifically,

167. Ibid., p. I69.

168. Ibid.

I69. For the argument that "universalist" and "nationalist" nationalism are not as distinct as most thinkers, including Hobsbawm, think, see J. Habermas, "The European Nation-State: On the Past and Future of Sovereignty and Citizenship", in idem, The Inclusion of the Other: Studies in Political Theory, C. Cronin and P. De Greiff (eds), (Oxford, I99 I, repr. 2000), pp. I I I-I I 7. In addition, see B. Yack, "The Myth of the Civic Nation", Critical Review, ro (1996), pp. I93-2 I I. I70. Hobsbawm, "Ethnicity and Nationalism Today", p. 4. For Anderson's claim see Imagined Communities, p. I4I. For a critique of Anderson's representation of nationalism, see Balakrishnan, "The National Imagination", p. 204. Hobsbawm's representation of modern nationalism has also drawn the ire of other scholars who claim that Hobsbawm's theory of nationalism is explicitly "Eurocentric". For this charge, see Lazarus, Nationalism and Cultural Practice in the Postcolonial World, p. 70, and A. McClintock, Imperial Leather: Race, Gender and Sexuality in the Colonial Context (New York [etc.], I995), p. I I. But compare these views with that of Homi K. Bhaba in his "DissemiNation: Time, Narrative, and the Margins of the Modern Nation", in idem (ed.), Nation and Narration (London [etc.], 1990), p. 29 I.

I71. Hobsbawm, Nations and Nationalism since 1780 , p. 178 .

172. Ibid., p. I79. 
the sort that was based on ethnic and linguistic homogeneity, but, above all, because he believed that "citizen nationalism", modern-day manifestation of Enlightenment universalism, had a future as an opponent of capitalist globalization beyond the "end of history". ${ }^{173}$ Recalling his somewhat ambivalent argument about the future of the nation-state, Hobsbawm argued in the mid-I990s that "citizen nationalism" constituted not only the primary but the only realistic defense against the brutalizing effects of capitalist globalization and the significant, if errant, force of identity politics.

His commitment to the virtues of citizen nationalism, of course, also recalled his almost life-long belief in the efficacy of the Popular Front. Like the cause of anti-fascism, citizen nationalism, he asserted, was a form of "identity politics" which was "based on a common appeal", ${ }^{174}$ and which could potentially marry national identity to social transformation. Hence, in the face of the "savageries of identity politics", ${ }^{175}$ Hobsbawm implored the Left (once again) "to recapture [national symbols] and, as it were, to refuse the devil's armies the monopoly of the best marching tunes". ${ }^{176}$ As a descendent of the eighteenth-century Enlightenment, citizen nationalism, Hobsbawm believed, was "the only foundation for all the aspirations to build societies fit for all human beings to live in anywhere on the Earth, and for the assertion and defense of their human rights as persons". ${ }^{177}$ Citizen nationalism or barbarism - these were the alternative futures that Hobsbawm supposed humanity faced in the new century.

What might account for Hobsbawm's shift from socialist politics to a politics of "citizen nationalism" in the late twentieth and early twenty-first centuries? First Hobsbawm believed that nationalism was now the "inescapable" ground of politics. For him, "national consciousness" constituted "the soil in which all other political sentiments grow". ${ }^{178}$ This conclusion was in keeping with his assessment that "where ideologies are in conflict the appeal to the imagined community of the nation appears to have defeated all challengers", ${ }^{179}$ including the socialist internationalism

173. Hobsbawm, The New Century, p. 88.

174. Idem, "Identity Politics and the Left", p. 45. Hobsbawm is now making much the same arguments as his opponents in the I970s in the debate over the nexus between socialism and nationalism. See T. Nairn, "Post-200 I and the Third Coming of Nationalism", Arena Journal, 2 I (2003), pp. 8I-97.

175. The phrase is Aijaz Ahmad's. See his "Preface" to Lineages of the Present: Identity and Politics in Contemporary South Asia (London [etc.], 2000), p. xii.

176. Hobsbawm, Nations and Nationalism since 1780, p. I45. See also idem, "The Crisis of Today's Ideologies", New Left Review, I/I92 (1992), p. 64.

177. E. Hobsbawm, "Barbarism: A Users Guide", New Left Review, I/206 (I994), pp. 46-47. Italics in the original.

178. Idem, Nations and Nationalism since I780, p. I45. On this point, Hobsbawm is in agreement with Benedict Anderson. See his Imagined Communities, p. 3.

179. Ibid., p. I63. 
which had originally inspired his attachment to world revolution. "We are all nationalists now"180 - the words are John Dunn's but Hobsbawm would agree with the sentiment.

What was important, according to Hobsbawm, was what sort of nationalists we were. The only way that a future, an all too possible future, conducive to the imagined community of Le Pen or Tudjman could be averted, he believed, was through the reassertion of the values of citizen nationalism - values, that is, attached to the eighteenth-century Enlightenment project. ${ }^{18 \mathrm{I}}$ In terms of Hobsbawm's biography, this was a politics that recalled the England of 1936 rather than the Germany of 1932. In the prevailing circumstances at the century's fin de siècle, this politics, accordingly, was a popular front with the socialism left out - not a politics figured to advance socialism but a politics designed to salvage something from the wreckage of its ruin.

A second explanation of Hobsbawm's shift in politics, linked to the first, provides a deeper solution to the question. Hobsbawm's politics of "citizen nationalism" accorded with his recently established assertion that the materialist conception of history did not provide an adequate resource for the attempt to change the world. In effect, Hobsbawm's citizen nationalism constituted a recognition that what he considered the central axioms of Marxian politics - "the sense that the triumph of socialism is the logical end of all historical evolution to date; and the sense that it marks the end of 'prehistory' in that it cannot and will not be an 'antagonistic' society" ${ }^{182}$ - could no longer be entertained. For Hobsbawm, as a means of changing the world, as opposed to a means of interpreting the world, Marxism was dead - especially if it persisted in opposing nationalism. In a world where both nationalism and capitalism appeared something like permanent realities, socialist internationalism, he argued, was not just utopian but impossible. Henceforth Mazzini rather than Marx would constitute Hobsbawm's political guide for the new century. ${ }^{183}$

In truth, however, Hobsbawm's citizen nationalism conflicted with other moments in his most recent assessment of the national question. For

I80. J. Dunn, Western Political Theory in the Face of the Future (Cambridge, 1979), p. 56.

I8I. Hobsbawm, "The Crisis of Today’s Ideologies", p. 64. At times, however, Hobsbawm's "citizen nationalism" could descend into what looked uncomfortably like "nationalist" nationalism; for example, in Interesting Times, where he argued that "The stubborn rearguard action of France in defiance of the global role of her language and culture may be doomed, but it also a necessary defence, by no means predestined to failure, of every language, and national and cultural specificity against the homogenization of an essentially plural humanity by the processes of globalization." See Hobsbawm, Interesting Times, p. 337.

I 82. E. Hobsbawm, "Marx and History", in idem, On History, p. I64. This essay first appeared in New Left Review, I/I43 (1984) pp. 39-50. Reference in this article will be to the essay as it appeared in On History.

I83. Anderson makes this more general point about Hobsbawm's politics. See his Spectrum, p. 3 I 2. 
example, it was out of step with his almost "Luxemburgist" belief that "a 'nation', however we define it, is by definition exclusive and particular". ${ }^{184}$ When advertising the merits of citizen nationalism, he directly contradicted this statement. Similarly, his citizen nationalism was bereft of the acute judgment, found in both The Age of Revolution and Nations and Nationalism since 1780 , that even "universalist" nationalism contained the potential to turn into its opposite - that is, universalist nationalism was perpetually vulnerable to ethnic and particularistic immolation. ${ }^{185}$ In addition, even in his most trenchant endorsement of "citizen nationalism" - where he advised the Left to appropriate the language of "national interest" - he could still remark that a political discourse rooted in conceptions of "the community" constituted an "ideological cop-out". ${ }^{186}$ If "the community" could be described in such terms, why not "the nation"? And, finally, his "citizen nationalism" conflicted with his belief that the major problems that faced the world in the new century - global ecological crisis, the growing gap between rich and poor, and the exponential growth of chemical and biological weapons - could not be solved within the framework of the nation-state. ${ }^{187}$ Solutions to these problems, he speculated at such moments, would need to be global not local. In such circumstances, citizen nationalism would appear an inadequate telos for the establishment of a society fit for all humanity.

Given the global nature of the problems capitalism's accumulation process has induced, it might have been supposed that the only imaginable alternative to global capitalism was one that mirrored its reach - a global socialism that transcended nationality and the national state. This is something like the homeland that Hobsbawm identified with on the streets of Berlin in the shadow of Hitler's rise to power: "a movement for all humanity", ${ }^{88}$ whose aim was "the emancipation of mankind". ${ }^{89}$ However, as Hobsbawm increasingly realized, you have to be positioned somewhere to say anything at all ${ }^{190}$ - and that "somewhere" was most often a nation state. Just as socialists have always been forced to operate in national paradigms, so actually-existing socialism of whatever type has so far been dependent on territorial embodiment. ${ }^{191}$

I84. Hobsbawm, "The Nation and Capitalist Globalization”, p. I.

I 85. Hobsbawm, The Age of Revolution, p. 165 , and idem, Nations and Nationalism since 1780 , pp. I68-169.

186. Idem, "Identity Politics and the Left", p. 47. A very different understanding of "community" is provided in P. Chatterjee, "Whose Imagined Community?", in Mapping the Nation, pp. 214-225.

i 87. Hobsbawm, “The Crisis of Today's Ideologies", pp. 58-59 and 64.

I88. Idem, Interesting Times, p. I 38 .

189. Idem, "The Emancipation of Mankind", p. I 87.

190. S. Hall, "Ethnicity: Identity and Difference", in Becoming National, p. 347.

I9I. For a superb short evocation of the problems of socialist internationalism, see T. Eagleton, "Nationalism: Irony and Commitment", in T. Eagleton, F. Jameson, and E. Said, Nationalism, 
If socialist internationalism appeared an unlikely terminus of world history however, no more realistic was "socialism (or social democracy ${ }^{192}$ ) in one country", for reasons well illuminated in Hobsbawm's work. To the degree that the nation state has been undermined by capitalist globalization, he explained, social democracy had suffered the most severe setbacks. Indeed, he believed that capitalist globalization was the precipitate cause of social democracy's ruin: “The advance of the globalized economy struck at the foundations of the social-democratic Left, because it undermined its ability to defend its social constituency within national borders through a re-distributive fiscal policy, welfare, and macro-economic stimulation of full employment." ${ }^{93}$ At the beginning of the new century, the prospects for socialist internationalism and nationalist socialism, of world revolution and a socialist-inspired Popular Front, Hobsbawm argued, appeared hopeless. There was no journey, he concluded, only different types of detour.

Marxist and non-Marxist commentators alike have repeatedly claimed that nationalism constitutes "Marxism's great theoretical failure". ${ }^{194}$ Indeed, according to one commentator, Marxists have not just got nationalism wrong, they have systematically evaded it. ${ }^{195}$ The claim is wide of the mark when applied to the Marxist historian, Eric Hobsbawm. Hobsbawm has long been critically engaged with varied dimensions of the national question. As might be expected from a historian without a fixed home, Hobsbawm has swung between differing understandings of the national question, sometimes settling on a version which mimicked his life history of displacement and exile, sometimes reacting against that personal history by offering an understanding of the nation-state and nationalism as perpetual features of humanity's future. His engagement with nationalism in other words has been marked by tensions derived from a political biography coterminous with the history of twentieth-century socialism.

Emotionally committed to the project of world revolution, he has at times rejected nationalism tout court, seeing it only as a form of ideology that covers over class divisions within nation states, here alert to the way that the marriage between socialism and nationalism has most often worked in nationalism's favor. In other moods, his version of nationalism has pointed away from this conclusion. Staring socialist defeat in the face, he has considered nationalism a perennial feature of modern society and

Colonialism and Literature (Minneapolis, MN, 1990), p. 34. For a more prosaic demonstration of these problems, see J. Dunn, "Unimagined Communities: The Deceptions of Socialist Cosmopolitanism", in Idem, Rethinking Modern Political Theory (Cambridge, 1985), p.105.

192. See G. Therborn, "Social Democracy in One Country", Dissent, Fall (2000), pp. 59-65, for a more positive perspective on social democracy's future.

193. Hobsbawm, The New Century, p. I02. See also idem, Age of Extremes, p. 417.

194. T. Nairn, "The Modern Janus", New Left Review, 94 (1975), p. 3.

195. Anderson, Imagined Communities, p. 3. 
has counseled socialists to make their peace with it. In the absence of a viable socialist project he has even fallen back upon a certain version of nationalism as the only safeguard against a future characterized by barbarism. At once confirming nationalism's victory over socialism and the seemingly perpetual existence of national belonging, such a politics has given rise to a series of ambiguities in Hobsbawm's understanding of Marxism's national question. Ambiguity - whether in interpretation or politics - is not always unproductive however. It has certainly not been unproductive in the case of Hobsbawm, who, in his encounter with the national question, has provided us with an intellectually decisive encounter between a Marxist and his nationalist world. 